\title{
55. HISTORY OF THE MEDITERRANEAN SALINITY CRISIS
}

\author{
Kenneth J. Hsü, ${ }^{1}$ Lucien Montadert, ${ }^{2}$ Daniel Bernoulli, ${ }^{3}$ Maria Bianca Cita, ${ }^{4}$ Albert Erickson, ${ }^{5}$ Robert E. \\ Garrison, ${ }^{6}$ Robert B. Kidd,${ }^{7}$ Frederic Mélières, ${ }^{8}$ Carla Müller, ${ }^{9}$ and Ramil Wright ${ }^{10}$
}

\begin{abstract}
An equatorial ocean existed during the Mesozoic between Africa and Eurasia known as Tethys. The Alpine Orogeny, culminating in the late Eocene and Oligocene, eliminated much of this ancient ocean. However, the relic Tethys, combined with the newly created post-orogenic basins, still retained host to a Mediterranean seaway. The link was first broken in the Burdigalian with the collision of Africa and Eurasia along the Middle East front. This event started the gradual changes towards a cooler and drier climate in regions which were now situated on the west side of a continent.

Middle Miocene movements cut off forever the opening on the east to the Indo-Pacific. Also the Perialpine Depression north of the Alps was raised and the communication between the Mediterranean and the Paratethys was severed. The considerable fresh-water supply from Central Europe was then diverted to the Paratethys, and the reorganization of drainages placed considerable strain on the water budget of the Mediterranean. Finally, soon after the beginning of the Messinian stage, the last opening to the Atlantic, the Betic and Rif straits were closed. Evaporative drawdown of the isolated Mediterranean sea level, leading to desiccation, became unavoidable, since evaporative loss considerably exceeded precipitation and influx from rivers.

The Mediterranean Evaporite can be divided into two units. The deep-sea drilling did not penetrate the Main Salt or the lower unit. The history of the onset of the salinity crisis and of the early salt deposition has been told by studies of sections on land. The land record in Italy indicates a very sudden change from deep, open marine conditions to environments of shallow-water carbonate evaporite deposition and of subaerial diagenesis. This first desiccation was followed by the deposition of the Main Salt unit. A thick body of salt was built by the evaporation of seawater spilled over from the Atlantic into Mediterranean brine lakes of considerable depth.

An intra-Messinian desiccation led to widespread erosion and recycling of primary halites. The Upper Evaporite deposition followed a marine flooding which may have again filled the Mediterranean to the brim. Evaporative drawdown of the Mediterranean sea level and the gradual concentration of the brines led to formation of evaporites characterized by the "bull's eye" pattern of saline zonation: Dolomite was the earliest mineral formed, followed by sulfate deposition. Halite was laid down on the bottom of playas, which are now abyssal plains, and the potash salts were
\end{abstract}

${ }^{1}$ Geological Institute, ETH, Zurich, Switzerland.

${ }^{2}$ Institut Français du Pétrole, Rueil-Malmaison, France.

${ }^{3}$ Geologisches Institute, Universität Basel, Basel, Switzerland.

${ }^{4}$ Istituto di Geologia, Universita, Milano, Italy.

5 Department of Geology, University of Georgia, Athens, USA

${ }^{6}$ Earth Sciences Board, University of California, Santa Cruz, USA.

${ }^{7}$ Institute of Oceanographic Sciences, Wormley, U.K.

${ }^{8}$ Laboratoire de Géologie Dynamique, Université de Paris, Paris, France.

${ }^{9}$ Geologisch-Paläontologisches Institut, Johann Wolfgang Goethe Universität, Frankfurt, W. Germany.

${ }^{10}$ Department of Geology, Beloit College, Beloit, USA. 
restricted to the deepest and most central parts of the Mediterranean basins. Repeated flooding and desiccation led to the accumulation of cyclically deposited sediments. Shallow-water diatoms and algal stromatolites prove that the basins were covered by very shallow waters during the flooding stage, and sedimentary structures indicate subaerial exposure during the desiccation stage of these cycles.

The Mediterranean was underlain by a series of desert and salt lakes towards the end of the Messinian, when the eastern Mediterranean was inundated by brackish water, probably from a Paratethys source. A number of lakes known collectively as the "Lago Mare" came into existence. Marl, or dolomitic marl with an Ammonia-Cyprideis fauna was deposited in many of these lakes. The western Mediterranean may have remained desiccated until the Atlantic water began to spill over the western portal. The infill began with the deposition of marls with restricted marine, dwarf faunas.

The final and irrevocable flooding of the Mediterranean took place at the beginning of the Pliocene. Normal marine circulation has prevailed ever since that time.

\section{INTRODUCTION}

The discovery of the Mediterranean Evaporite formation by the drilling from Glomar Challenger in 1970 proved that salt exists under deep sea floor (Ryan, Hsü et al, 1973). We could no longer avoid the issue of salt genesis in ocean basins by assuming that diapiric structures on seismic profiling records on the Atlantic margins, the Mediterranean, and of the Gulf of Mexico are mud diapirs. The fact was also brought home that giant salt deposits could have been formed within a relatively short geologic time: No longer could the genesis of enormous evaporite deposits be related to lateral accretion of coastal salina deposits, consequent upon facies migration. The synchronous onset and termination of the pan-Mediterranean salinity crisis implies drastic changes of environmental conditions in a region over two and half million square kilometers in extent, and that these changes took place within tens or hundreds of thousand years. The discovery of the Messinian Mediterranean Evaporite was the nail into the coffin of Lyell's substantive uniformitarianism. It is not surprising that we should have heard again calls for a restrained return to catastrophism (e.g., SylvesterBradley, 1973).

The significance of the DSDP discovery was, however, overshadowed by disagreements over the genesis of the Mediterranean Evaporite. That the Mediterranean Evaporite formation was Messinian in age seemed to be just about the only consensus after the Leg 13 drilling. Even the shipboard scientific staff could not reach an agreement on the genesis of this unusual formation. Chapter 43 of the Leg 13 cruise report presenting the desiccated deep-basin model was authored by K. J. Hsü, Maria Cita, and W. B. F. Ryan because they were the only members of the shipboard staff totally convinced of its plausibility. Alternative interpretations were given by other shipboard staff in the Volume 13 Initial Reports and later in other publications (e.g., Nesteroff, 1973a, b; Wezel, 1974). The reactions of the scientific community to the desiccated deep-basin model were also divergent. Favorable com- ment was not rare, and journalists had a field day, headlining the story in the press, radio, and television, with reports of varying accuracy. On the other hand, many published critiques in scientific journals were skeptical, and some downright hostile. There was a widespread impression that a tall tale had been spun from a few core chips. This harsh judgment was partly justified in view of the modest amount of recovered core material. The porponents of the model were almost too shy to admit that the only drilling evidence for the presence of Messinian evaporites in the eastern Meditteranean was afforded by several chips of gypsum in a bucket of odorous mud scraped off the outer-bit after the drill string was taken out of Hole 125.

The importance of clarifying the question of the Messinian salinity-crisis did not escape the attention of the Joint Oceanographic Institutions for deep Earth Sampling (JOIDES) organization. A cruise to the Mediterranean was included in the very first schedule proposed by the JOIDES Planning Committee as soon as the Third Phase of DSDP was ascertained. Meanwhile, the Mediterranean Advisory Panel was reorganized to infuse new blood and to permit consideration of divergent viewpoints within the international scientific community.

The essence of the desiccated deep-basin model lies in the postulate that the Mediterranean basins as we know them today were largely in existence prior to the Messinian salinity-crisis, and that these basins were desiccated, or partially desiccated, one or more times to form the evaporite deposits that had been sampled. Leg 13 drilling had not penetrated very far beyond the top of the Messinian. We had very little data on preMessinian history, and we did not have many samples of the evaporites themselves. The emphasis in planning Leg $42 \mathrm{~A}$ was, therefore, to penetrate stratigraphically as deep as possible to obtain information on the geologic evolution of the Mediterranean prior to the salinity crisis. Secondly, a site in the central abyssal plain was to be drilled to provide as continuous a record as possible of this unusual event. 
Our aims were not completely fulfilled during the Leg $42 \mathrm{~A}$ drilling because of time constraints, technical limitations, and safety requirements. We did not drill beyond the lower Miocene, nor did we obtain a complete record of the Mediterranean Evaporite formation. Nevertheless, we have cored sufficient materials and have produced sufficient data to enable us to reach a near consensus on the previously controversial question of the origin of the Mediterranean Evaporite. This article is not a perfunctory report requiring co-authorship by the shipboard scientific staff. It is a unanimous opinion written by the senior author for 10 co-authors, who represent all but two of the shipboard scientific staff of Leg 42A.

\section{THE MIOCENE MEDITERRANEAN}

One of the most often debated questions during the March 1973 Utrecht Symposium on Messinian Events in the Mediterranean revolved around the basin depths of the evaporite depositions. The participants there seemed to have agreed that "evaporation took place under shallow water conditions, at least for the carbonates and sulfates" (Drooger, 1973). It was also agreed that the configuration of the Alpine-Mediterranean region was changed drastically by the Alpine orogeny. The orogenic movement had eliminated most of the oceanic area between Eurasia and Africa by the end of the Eocene (Argand, 1924). The Mediterranean is, therefore, at least in part a new creation. But which, if not all, of the Mediterranean basins were new? When did these new basins form? In the early and middle Miocene prior to the Messinian salinity crisis (e.g., Argand, 1924)? In the Pliocene shortly after the salinity crisis (Selli and Fabbri, 1971)? Or "did the main phase of subsidence occur rather abruptly during the Pleistocene and Holocene" (Neev et al., 1976)?

Many different tectonic models have been proposed to interpret the evolution of the Alpine Mediterranean system. From the classical approach of Argand (1924), to the plate-tectonic advocates of more recent years (Smith, 1971; Dewey et al., 1973), syntheses of regional geological data reached a conscensus that the Mediterranean had already evolved to a stage quite similar to the present configuration prior to the late Miocene when the salinity crisis began. Several of us had reviewed the tectonic data on land and under the sea, and had reached the same conclusion (Montadert in Biju-Duval et al., this volume; Hsü and Bernoulli, this volume). Of the five major Mediterranean basins (Figure 1), the Levantine and Ionian basins may be relics of Tethys and of Mesozoic age; the Balearic and Tyrrhenian basins were formed during the early and middle Miocene, after the acme of the Alpine orogeny; only the Aegean may have owed its origin primarily to Pliocene-Quaternary subsidence. We shall not repeat all the arguments here and the readers are referred to these two synthesis chapters of this volume.

Deep-sea drilling during Leg $42 \mathrm{~A}$ has unearthed convincing evidence that deep Mediterranean basins were in existence prior to the Messinian. Drilling at Site 372 indicated that the Balearic Basin was formed by rifting during the latest Oligocene or earliest Miocene time (Figure 2). Paleobathymetric analyses on the basis of benthic foraminifers estimated that this part of the Balearic margin had a water depth of at least 900 meters as early as Burdigalian time. The water depth reached in excess of 1200 meters during the late Burdigalian and had subsided gradually to a depth more than 1500 meters prior to the end of the Serravallian (Figure 3, see also Wright, this volume). In addition to the initial subsidence associated with the rifting phase of the basin, the Balearic Basin may have continued to subside during the Neogene in response to mantle cooling. Furthermore, the accumulation of the thick salt deposits and the eventual flooding of a desiccated deep basin must have induced considerably more subsidence in isostatic response to these additional loads. We do not question the evidence that

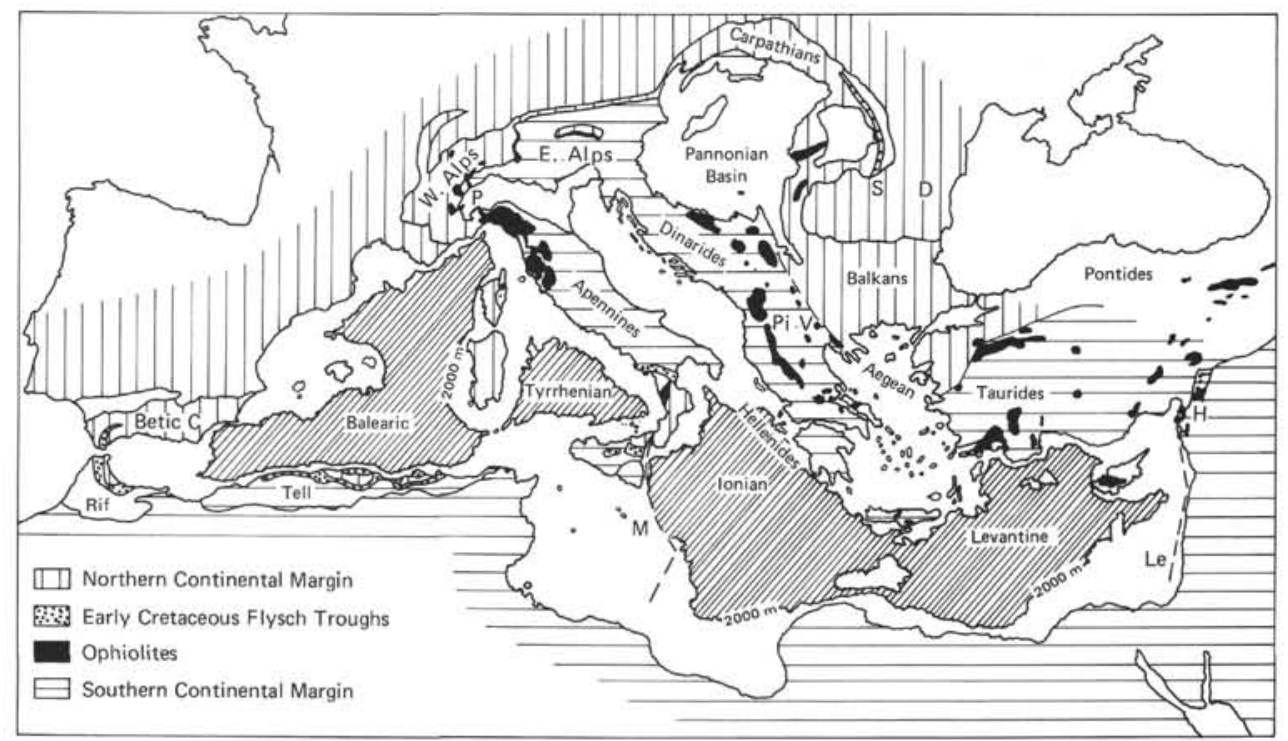

Figure 1. Tectonic setting of the Mediterranean basins (from Hsü and Bernoulli, this volume). 


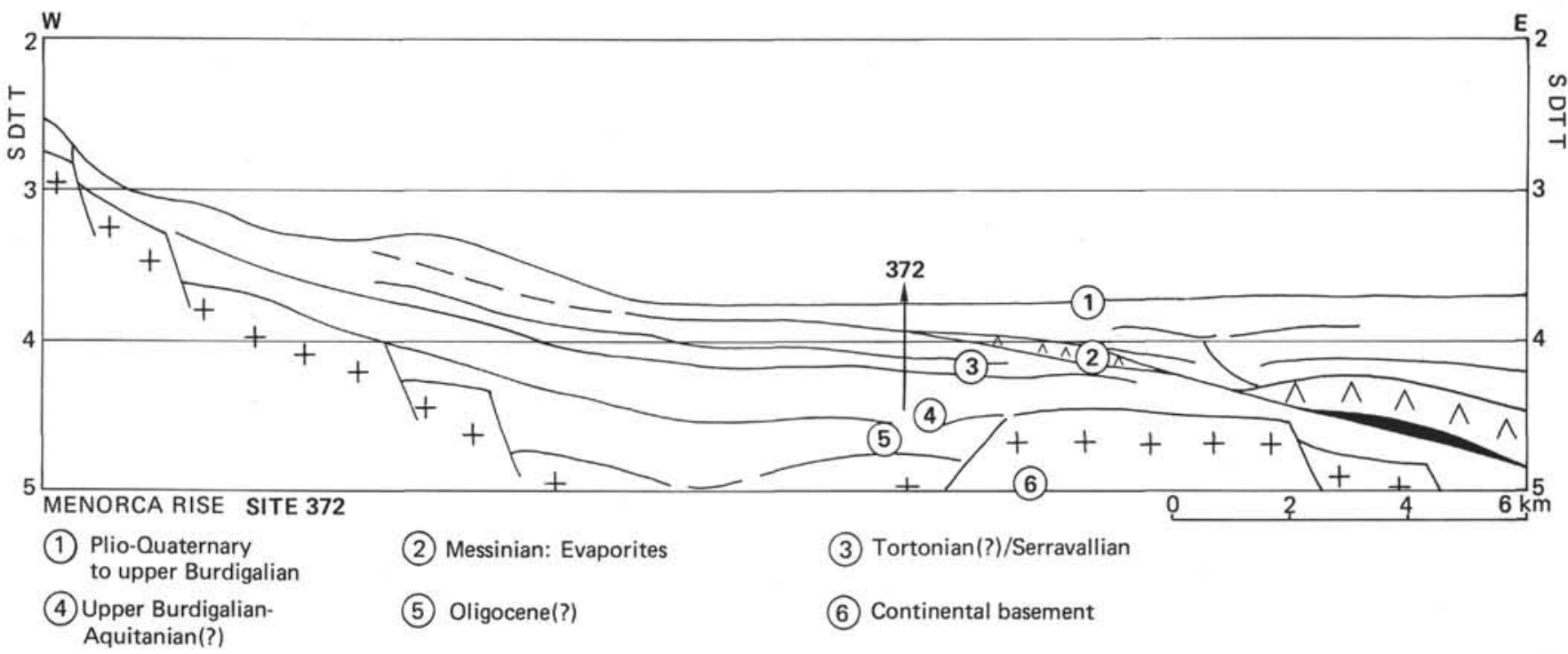

Figure 2. Rifted margin of the Balearic Abyssal Plain (after Hs̈̈ et al., 1975).

there has been subsidence during the Pliocene-Quaternary. However, there is no evidence that the Balearic Basin was a shallow shelf sea prior to that subsidence. In fact seismic evidence proves the existence of a deep Balearic Basin long before the salinity crisis began. The wedge of the sediments at the Balearic margin north of Majorca near the pre-Messinian escarpment is about 1000 meters thick (Figure 4). The same thickness was observed on the Catalania margin, on the "old" margin at the approach to the Gulf of Valencia, and probably also in the Gulf of Lyon (Montadert et al., this volume).

The pre-Messinian sequence at Site 372 is mainly hemipelagic, similar to the sediments deposited there today (Figure 5, see also Chapter 3, this volume). The planktonic and benthic fauna and flora are fully open marine. As well as benthic foraminifers, the study of which formed the basis of a systematic paleobathymetric analysis, psychrospheric ostracodes also occur in some Burdigalian and Serravallian cores and indicate water depths in excess of 1000 meters. Similar psychrospheric ostracodes are present in the middle Miocene of the Betic in Andalusia and in the DSDP cores from the Atlantic; these occurrences suggest an oceanic continuity at that time between the Mediterranean and the Atlantic (Benson, this volume). Isotopic analysis of the planktonic and benthic foraminifers shows a large difference in the values of $\delta \mathrm{O}^{18}$, which has been interpreted to mean a temperature difference between the surface and the bottom of some $10^{\circ} \mathrm{C}$ (Grazzini, this volume). The difference implies the existence of a middle Miocene Balearic Sea of considerable depth. Assuming that Mediterranean bottom waters of that period were contributed by the ocean with a $\delta$ around $-1.2 \%$ on the PDB scale (Shackleton and Kennett, 1975), the bottom temperature of the lower Miocene sea should have ranged between $7^{\circ}$ to $12^{\circ} \mathrm{C}$, average $8.5^{\circ} \mathrm{C}$ ( Grazzini, this volume). This conclusion, in our opinion, confirms the ecologic interpretation of psychrospheric ostracodes by Benson (this volume).
Drilling results at Site 373 indicated that the Tyrrhenian Basin was also in existence prior to the Messinian. The drill string penetrated some 200 meters into the top of the seamount there and cored tholeiitic basalts. The chemistry of the basalts is comparable to that of the Pacific marginal basins or that of spreading midocean ridges, and is distinctly different from that of alkali basalts on land or in rifted continental valleys (Barbieri et al., this volume; Dietrich et al., this volume). Pillow structures and isotopic evidence also indicate submarine eruption. The Tyrrhenian basalts have been dated radiometrically to range from late Miocene to early Pliocene, showing that the seamount volcanism there ceased to be active during the Pliocene, or about 3.5 m.y.B.P. However, the seamount grew at a slow rate of about $40 \mathrm{~m} / \mathrm{m}$.y. The submarine volcanism that was responsible for the growth of the seamount must have started considerably earlier than 7.5 m.y. (or the age of the oldest core obtained). We might thus speculate that the rifting of the Tyrrhenian and the accompanying submarine volcanism was a middle or early Miocene event. Furthermore, the bathymetry, the structure, and the history of volcanism suggest that the Tyrrhenian Basin is a younger feature than the Balearic; the submarine volcanism, and presumably the processes leading to the subsidence of the Tyrrhenian continued from the Miocene to the Pliocene Quaternary and on to the present. Nevertheless, the genesis of the basins began, and the central portion of the basin most probably sank to bathyal depths, prior to the Messinian salinity crisis. That the Tyrrhenian was already a deep-sea basin at the very beginning of the Pliocene has been established by the drilling results of Leg 13 (Ryan, Hsü, et al., 1973). The occurrence of basalt breccias in Hole 373A supports this interpretation. The paleotemperature for the submarine cementation (by calcite) of the breccias was estimated by isotopic evidence to be $6^{\circ}-8^{\circ} \mathrm{C}$ (Bernoulli et al., this volume). Such a low temperature for the early Pliocene seabottom implies that the seamount 


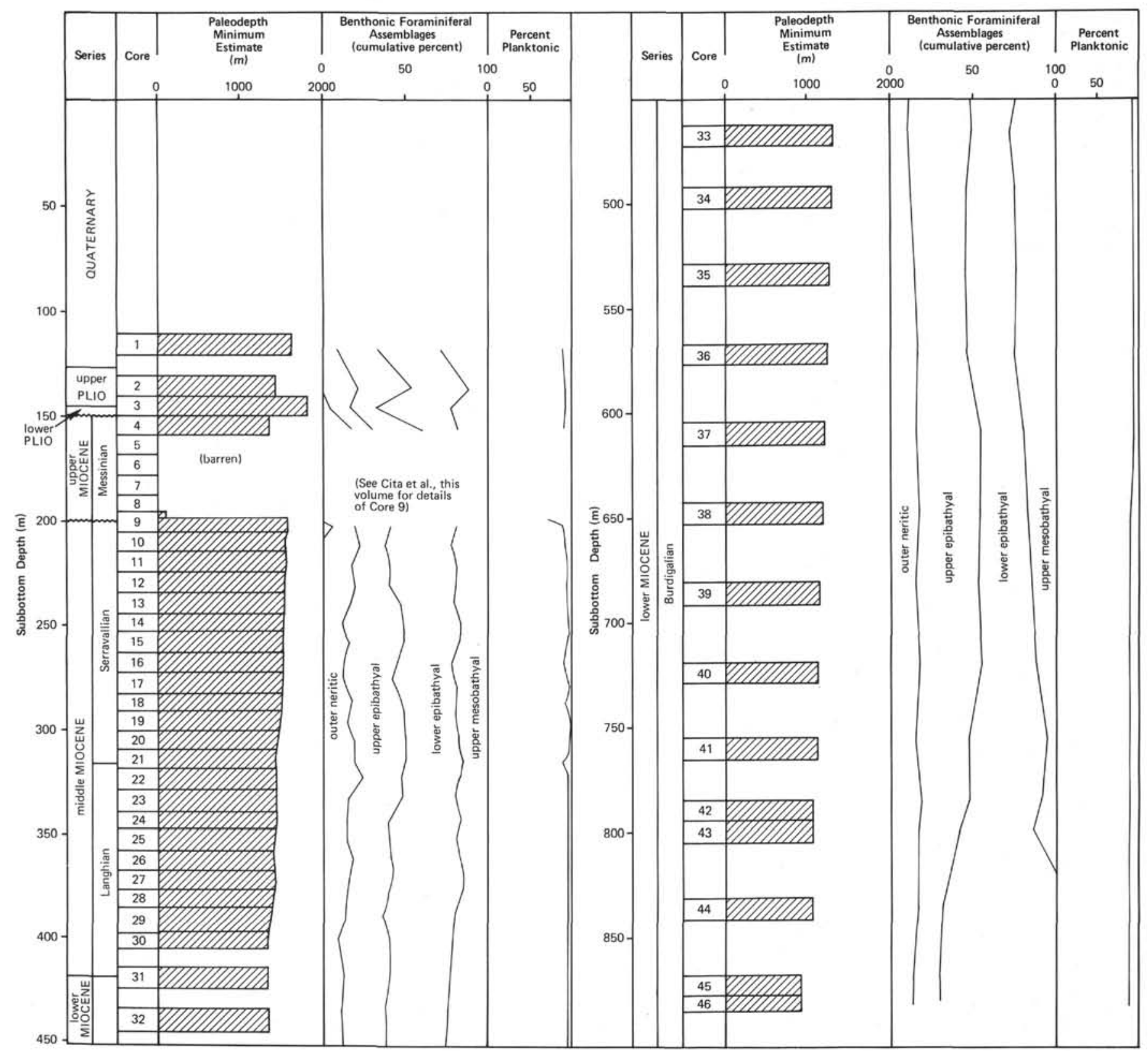

Figure 3. Paleobathymetric analysis of Site 372 (from Wright, this volume).

was submerged to a great water depth shortly after the salinity-crisis.

Our drilling penetrated beyond the Messinian at Site 375 on Florence Rise in the Levantine Basin (Figure 6). As in Hole 372, the pre-Messinian sequence in this eastern Mediterranean hole is also mainly hemipelagic. $\mathrm{Pa}$ leobathymetric analyses on the basis of benthic foraminifers were more difficult here, but the data are sufficiently compelling to indicate that the Levantine Basin was in existence during the early and middle Miocene and that the water depth reached in excess of 1000 meters during the Tortonian (Wright, this volume). Hole 375 penetrated only as far as the lower Miocene. However, the pre-Miocene history might be deciphered by correlation with land section on Cyprus, which is only $50 \mathrm{~km}$ east of Site 375 . On the island, in the northern part of Mesaoria and along the Kyrenia Range, a sedimentary sequence described by $\mathrm{Baroz}$ and Bizon (1974) is in part identical with the preevaporitic Neogene at Site 375 (Baroz et al., this volume). The Kyrenia sequence in turn is similar and passes laterally into the Tertiary deposits above the Troodos Massif described by Robertson and Hudson (1974). The Troodos was a fragment of the MesoTethys ocean overlain by Late Cretaceous and Tertiary oceanic sediments (Moores and Vine, 1971). The correlation with Cyprus thus suggests that this part of the Levantine Basin is underlain by thick pelagic and hemipelagic sequences above a deformed oceanic crust of late Mesozoic age. The very old age of the basin is manifested geothermally by the unusually low heatflow values measured here (Erickson, this volume). 


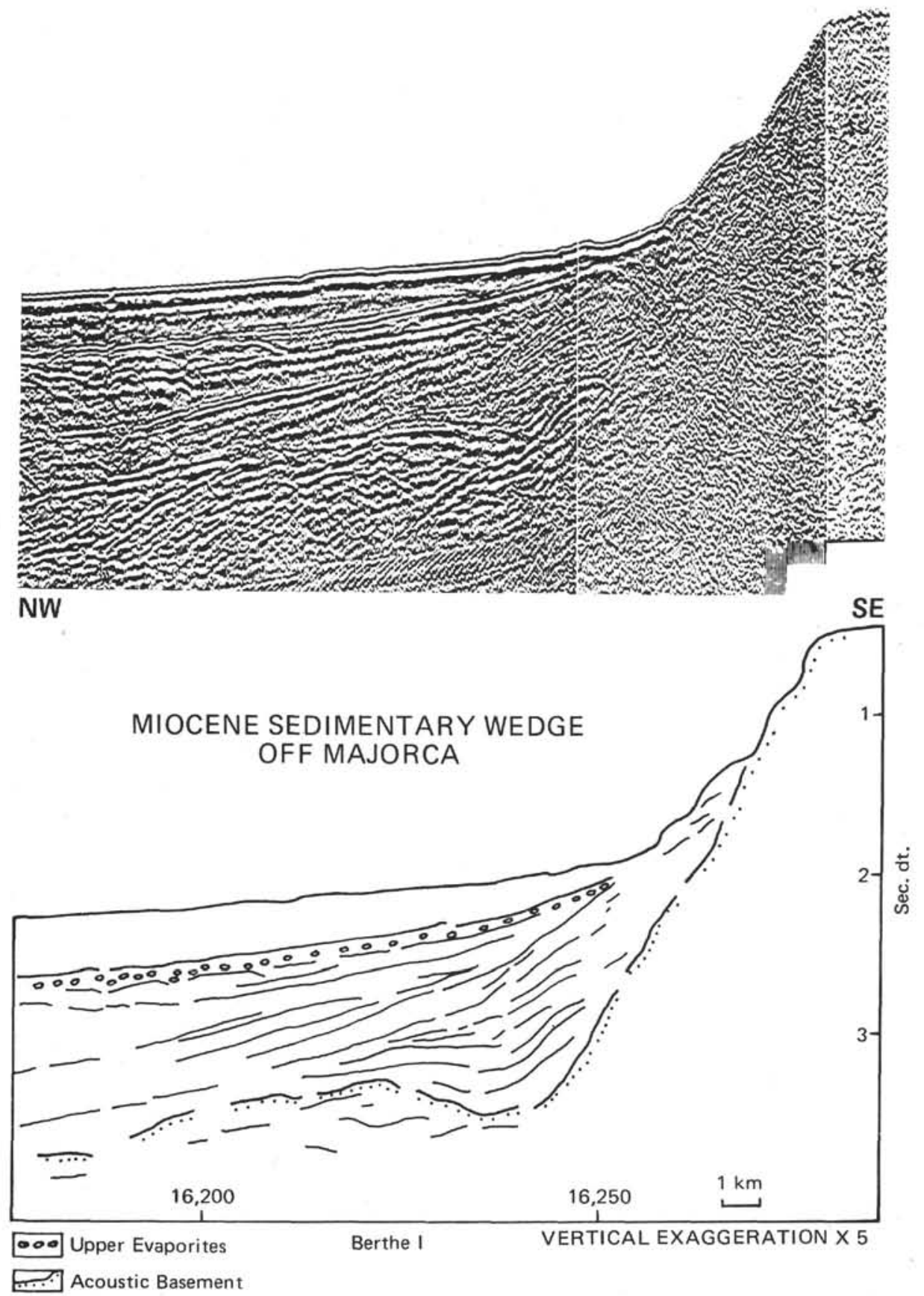

Figure 4. Seismic profile of the Balearic margin north of Majorca. Note that the wedge of sediment butting against the pre-Messinian basement is about $1 \mathrm{~km}$ thick (from Montadert, et al., this volume).

At Site 377 on the Mediterranean Ridge, we drilled into middle Miocene sediments. The pre-Messinian sediments there are not entirely hemipelagic: the black shales and cross-laminated siltstones were apparently deposited on a continental rise or in a basinal setting. The few samples yielded a poorly preserved benthic foraminifer fauna. A paleobathymetric analysis tentatively placed the fauna in the mesobathyal zone; greater than 1000 meters water depth. (Wright, this volume).

Whereas the paleobathymetric results from the eastern Mediterranean basins are less complete and less conclusive than those from the west, the tectonic evidence is more convincing. Syntheses of data from geology on land from off-shore drilling, from marine geophysics, and from deep sea drilling leave little doubt that the eastern Mediterranean is a relic of the Mesozoic Tethys (Biju-Duval et al., this volume; Hsü and Bernoulli, this volume). It has been undergoing compressional movement since the late Mesozoic and throughout the Tertiary. The Hellenic Arc, the Mediterranean Ridge, and the Cyprus Arc all underwent tectonic deformatins and uplifts, which are continuing today. An overview of available data cannot support the hypothesis by Israeli geologists (Neev et al., 1976; Gvirtzman and Buchbinder, this volume) 

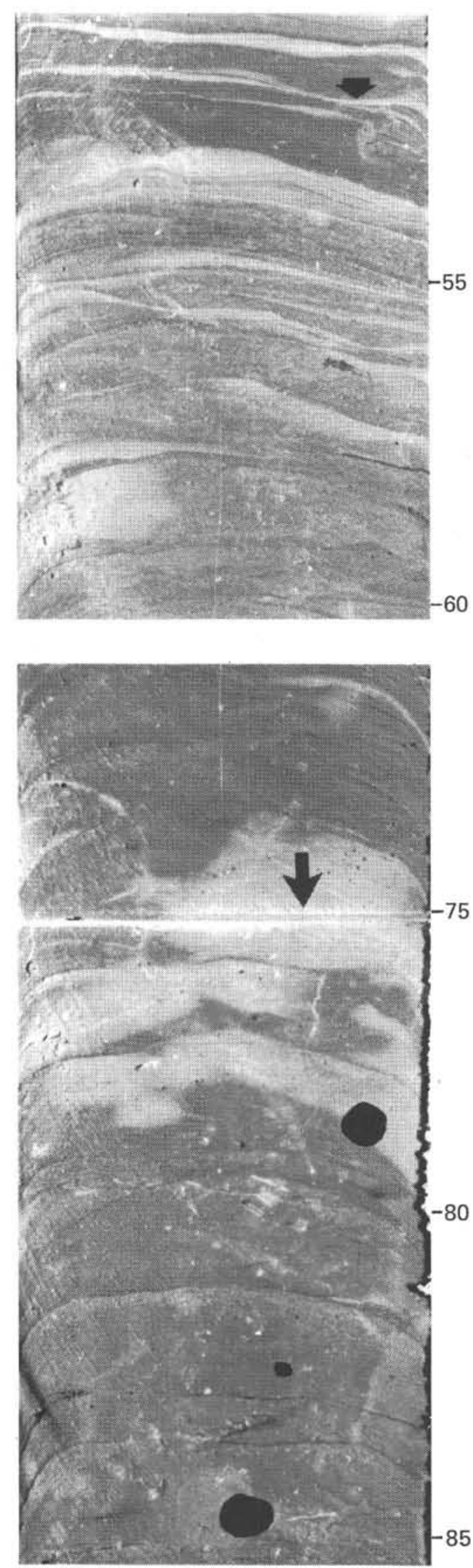

Figure 5. Hemipelagic sediments overlain unconformably by Messinian varve-like sedi- ments, Site 372, Core 9, Section 2 (from

Cita et al., this volume).

that the Levantine Basin hosted a shelf sea before it foundered abruptly during the Pliocene-Quaternary. There exists even less evidence to support the corollary of the hypothesis by Gvirtzman and Buchbinder (this volume) that the African and Arabian platforms were elevated thousands of meters above global sea level for about 2 million years only during the Messinian to account for the deep erosion of the Nile and other rivers emptying into the desiccated eastern Mediterranean.

The Aegean is obviously the youngest of the Mediterranean basins. The Aegean back-arc basins may have originated in the middle Miocene (Biju-Duval et al., this volume). Vertical movements continued during the Tortonian when the marine waters invading the Aegean severed the connection of Crete from continental Europe (Meulenkamp and Zachariasse, 1973). The Cretan Arc was tectonically active during the PlioceneQuaternary and is still active today (Hsü and Ryan, 1974; Papazachos, 1975) and there has been considerable Aegean subsidence during the Quaternary (See Site 378 report this volume). Hole 378 a penetrated the top of the Messinian, and sampled selenitic gypsum, which was deposited in an evaporite basin. However, we have little information on which to judge if this was a deep- or a shallow-water depression prior to the salinity crisis.

\section{EVENTS LEADING TO THE SALINITY CRISIS}

An equatorial ocean separated Europe from Africa during the Jurassic and Cretaceous known as Tethys (Neumayr, 1885; Suess, 1893; Hsü and Bernoulli, this volume). With the approach of these two continents, much of the Tethys was eliminated by the Alpine Orogeny (Figure 7). With the creation of the new Mediterranean basins after the orogeny, the connection between the Atlantic and Indo-Pacific was maintained until the early Miocene. This connection was severed with the joining of the two continents along the Middle East front during the Burdigalian (see Table 1). This was one of the major paleobiogeographical events of the Tertiary; it was during this period that "the present pattern of land and sea was established"' (Adams, 1973, p. 453). ${ }^{11}$ The immediate effect of this Burdigalian event on the Mediterranean sedimentation was rather obscure. We noted changes in lithology and some minor change in faunas from the early Burdigalian sediments of Unit IV to the late Burdigalian sediments of Unit III at Site 372 in the Balearic Basin (see Site 372 report, this volume). The long-term influence was, however, global: the joining of Europe and Asia permitted the exchange of land faunas between these continents, and started the differentiation of the IndoPacific and Atlantic-Mediterranean marine faunas (see

\footnotetext{
${ }^{11}$ The Atlantic and the Pacific did not lose their Central American connection until much later, but the effect of that event is beyond the scope of this paper.
} 


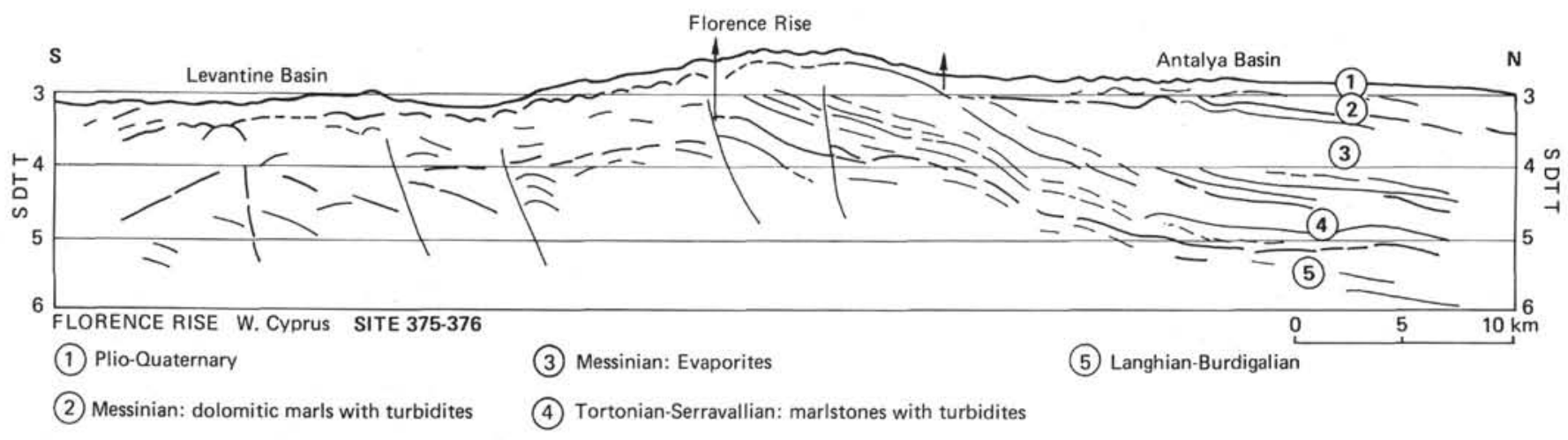

Figure 6. Structural cross-section across the Florence Rise. Note that the sequence has been subjected to compressional deformation during the Tertiary.

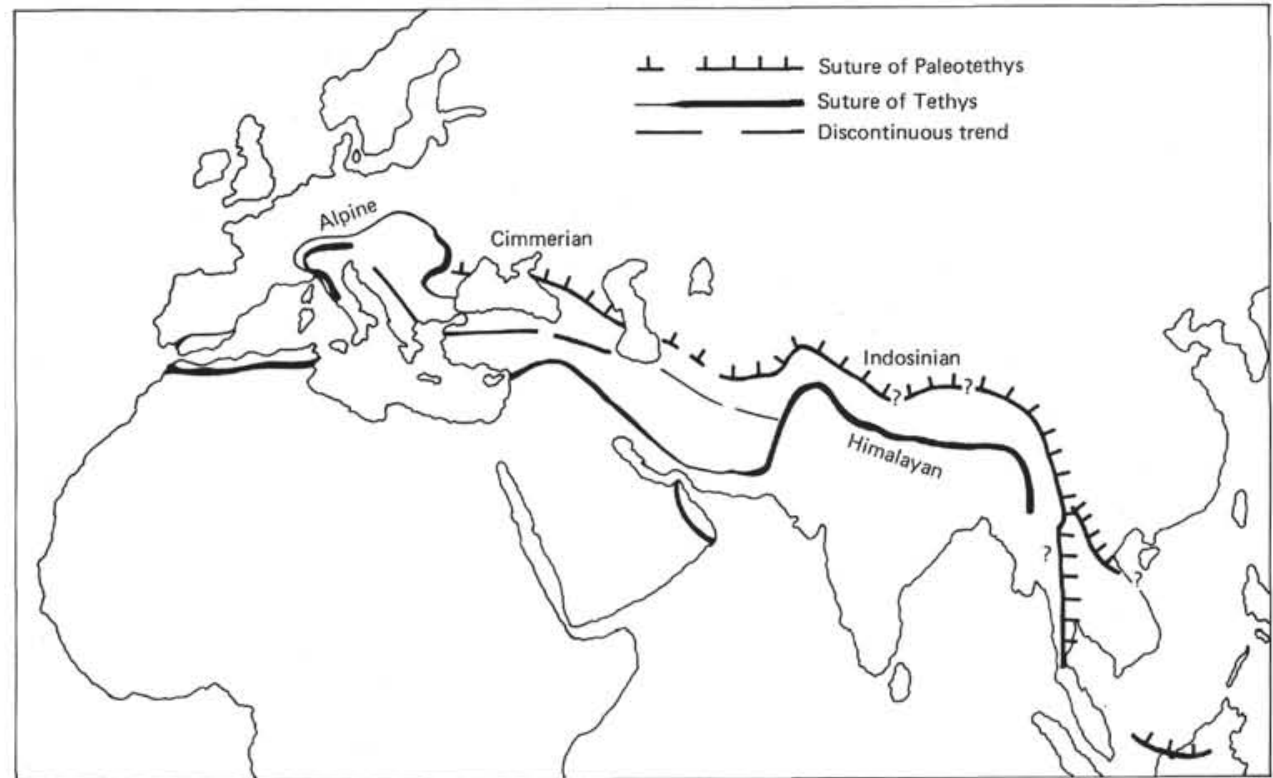

Figure 7. Tethys suture zones. Much of Mesotethys is believed to have disappeared by subduction along the Alpine-Himalaya suture zone (from Hsü and Bernoulli, this volume).

papers in Adams and Ager, 1967; Hallam, 1973). Whereas the evidence from vertebrate paleontology indicates the establishment of an intercontinental connection between Eurasia and Africa during the Burdigalian (Savage, 1967), the micropaleontological data suggest that there might have been repeated transgressions into the Mediterranean from the Indopacific until middle Miocene time (Rögl et al., this volume). The final severance of the Mediterranean link with the Indian Ocean probably took place at about 14 m.y.B.P., during the Serravallian (Buchbinder and Gvirtzman, 1976). A late Serravallian (14-13 m.y.) Indopacific transgression reached Paratethys, but did not enter the Mediterranean province.

The pattern of faunal distribution as we know it today was thus largely established during the middle Miocene; the Mediterranean was cut off from the Indian Ocean and the Indopacific species that had not already gained entrance were unable to do so. The joining of the continents also began a gradual change in the Mediterranean climate, which became increasingly more arid as is typical of regions in low latitudes on the west side of a continent. We might thus assume that the first seed of the salinity crisis was implanted in the Burdigalian and became viable in the Serravallian. It took some 15 million years of incubation before the crisis was born!

The orogenic movements which fused Eurasia and Africa also raised new mountains in the Taurides, the Hellenides, the Dinarides, and eventually, somewhat later in the middle or early late Miocene, the Helvetic Alps. This series of movements led to a separation of the Mediterranean from Paratethys. Land geology provides excellent information with which to reconstruct the paleogeography. The distribution of land and sea during the middle Miocene was as shown in Figure 8 , a figure modified from the text of Gignoux (1950), through the addition of deep-sea drilling information. 
TABLE 1

Outline of the History of Messinian Salinity Crisis

\begin{tabular}{|c|c|c|}
\hline Age & Event & Consequence to Mediterranean \\
\hline Burdigalian & Joining of Africa and Eurasia & $\begin{array}{l}\text { Loss of the connection to the Indian Ocean; Mediter- } \\
\text { ranean now on west side of a continent, with climatic } \\
\text { changes towards increasing aridity }\end{array}$ \\
\hline Serravallian & $\begin{array}{l}\text { Rise of Perialpine Depression } \\
\text { Tectonic movement in northern } \\
\text { Italy }\end{array}$ & $\begin{array}{l}\text { Loss of the connection to Paratethys; cutoff of con- } \\
\text { siderable fresh-water supply, straining the Mediter- } \\
\text { ranean water budget }\end{array}$ \\
\hline $\begin{array}{l}\text { After beginning of } \\
\text { Messinian }\end{array}$ & $\begin{array}{l}\text { Closure of the Betic and Rif } \\
\text { straits }\end{array}$ & $\begin{array}{l}\text { Loss of connection to Atlantic Ocean Evaporative } \\
\text { drawdown of Mediterranean sea level. Formation of } \\
\text { the Calcare di base }\end{array}$ \\
\hline $\begin{array}{l}\text { Messinian } \\
\text { Lower Evaporite }\end{array}$ & $\begin{array}{l}\text { Continuous influx of Atlantic } \\
\text { water into the Mediterranean, } \\
\text { without refluxing }\end{array}$ & Formation of the lower part of the Main Salt \\
\hline Intra-Messinian & Cutoff of seawater influx & $\begin{array}{l}\text { Intra-Messinian unconformity, erosion, and deposi- } \\
\text { tion of recycled salts (upper Main Salt) }\end{array}$ \\
\hline Intra-Messinian & Influx of Atlantic water & $\begin{array}{l}\text { Marine deposition at the base of Upper Evaporite; } \\
\text { transgression over the intra-Messinian unconformity }\end{array}$ \\
\hline $\begin{array}{l}\text { Messinian } \\
\text { Upper Evaporite }\end{array}$ & $\begin{array}{l}\text { Alternating closure and influx } \\
\text { from Atlantic }\end{array}$ & Cyclic sedimentation of the Upper Evaporite \\
\hline $\begin{array}{l}\text { Near end of } \\
\text { Messinian }\end{array}$ & Influx of water from Paratethys & $\begin{array}{l}\text { "Lago Mare" deposition in the eastern Mediterranean } \\
\text { basins }\end{array}$ \\
\hline End of Messinian & Influx of water from Atlantic & $\begin{array}{l}\text { Restricted marine deposition in the western Mediter- } \\
\text { ranean basins }\end{array}$ \\
\hline $\begin{array}{l}\text { Beginning of } \\
\text { Pliocene }\end{array}$ & $\begin{array}{l}\text { Opening of the Strait of Gibraltar } \\
\text { Flooding by Atlantic water }\end{array}$ & $\begin{array}{l}\text { Trubi Transgression } \\
\text { End of Messinian salinity crisis }\end{array}$ \\
\hline
\end{tabular}

The Paratethys was separated from the Mediterranean by the mountain chain which stretched from the Alps through the Dinarides and the Hellenides to Anatolia. Four possible connections between the two water bodies have been suggested; the link may have extended across (1) the peri-alpine depression (2) northwestern Yugoslavia, (3) the Bosporus, or (4) the Caucasus (Senes, 1973). At the beginning of the Miocene, the Bosporus certainly did not exist (see discussion later). Nor was there any evidence of early Miocene marine connections linking Paratethys and the Mediterranean across the mountains of Anatolia or the Balkans. Stratigraphic and paleobiogeographic data indicate that the Burdigalian connection between the two seas went through the Peri-Alpine Depression north of the Alps (Gignoux, 1950; Rögl et al., this volume). This seaway was eliminated early in middle Miocene, when the Helvetic Alps rose and marine waters withdrew from the Molasse trough; but a last thread of contact was maintained between the Mediterranean (Langhian) and the Paratethys (early Badenian) through an opening in northern Italy and northwestern Yugoslavia (Rögl et al., this volume). The complete separation of the two inland seas took place some 14 or 15 million years ago during the early Serravallian (Gheorghian and Popescu, 1975; Rögl et al., this volume). As mentioned above, the later and last Indopacific flooding invaded the Paratethys but did not reach the Mediterranean.

The middle Miocene separation had two consequences. The Paratethys could no longer receive marine waters from the Mediterranean nor could the Mediterranean receive fresh waters from those of the Eurasian rivers which now emptied themselves into the Paratethys. Furthermore when the connection was open, some of the surplus ions resulting from evapora- tive excess in the Mediterranean found their way to, and were deposited as lower middle Miocene salts in the Pannonian and Transylvanian basins (see the discussion of the Badenian Desiccation in Rögl et al., this volume). After the loss of communication, the Mediterranean was deprived of one of its means of elimination of evaporative waste; exchange with the Atlantic became its only possibility.

Now that the Paratethyan basins received such a large share of the fresh water from rivers, the Paratethyan waters evolved with a progressive freshening (Gheorghian and Popescu, 1975; Rögl et al., this volume). The Paratethys supported brackish and/or freshwater faunas even during Messinian time when the Mediterranean was evaporated dry (Senes, 1973; Rögl et al., this volume). Paratethys' gain was the Mediterranean's loss. The reduced influx of fresh water placed even greater stress on the water budget of the Mediterranean. We might thus blame the middle Miocene event for having nourished the trend toward a Mediterranean salinity crisis.

The Mediterranean's last links with the world ocean were the Betic and the Rif straits (Benson, this volume; Cita et al., this volume; Biju-Duval et al., this volume). With the relentless northward march of Africa, their fate was inevitable. The deep Betic Strait shoaled after the end of the middle Miocene; no Tortonian psychrospheric ostracodes have been found inside the Mediterranean (Benson, this volume). Nevertheless, weak links, similar to the Gibraltar Strait of today, seem to have been competent enough to keep the Mediterranean waters normal marine. Open marine planktonic and benthic fossils are found in lower Messinian sediments directly beneath the evaporites of land sections in northern Italy and in Sicily (see Cita et al., this volume). 


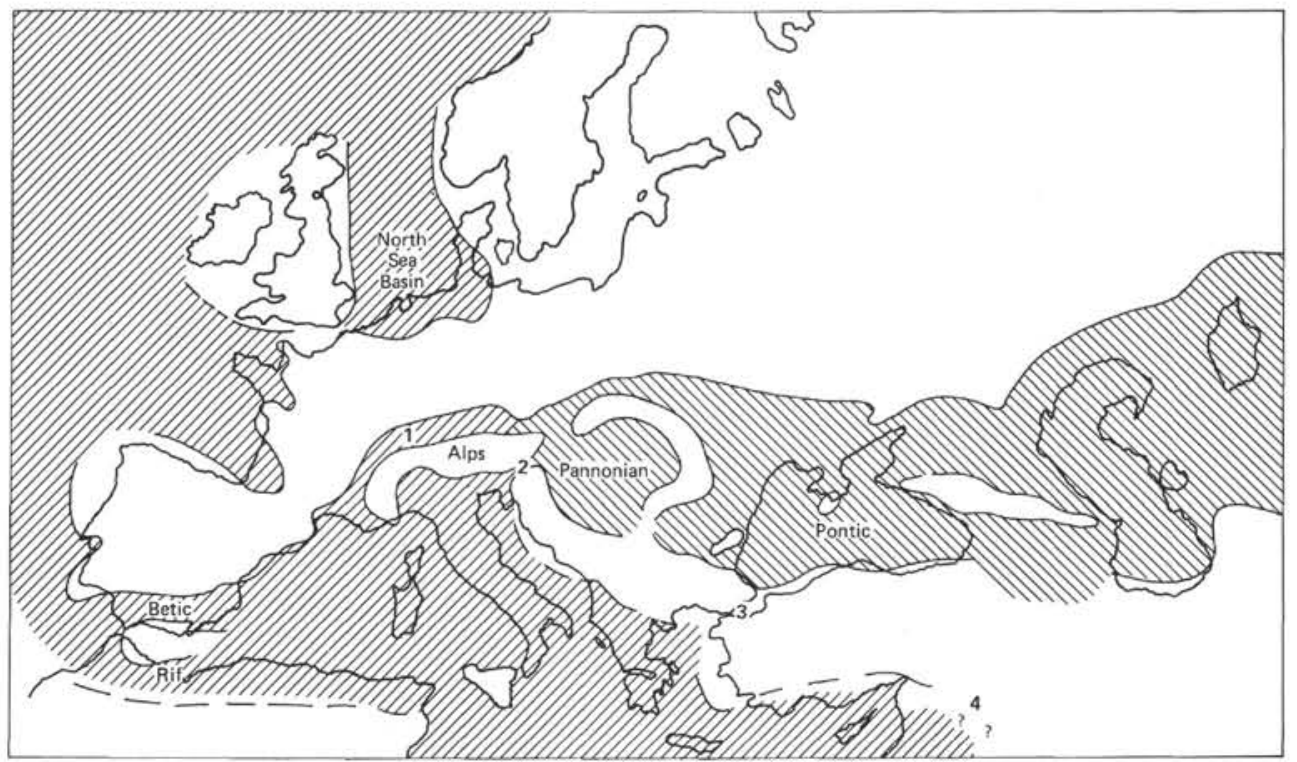

Figure 8. Relationship between the Mediterranean and Paratethys and also the Atlantic Ocean during early to middle Miocene. The shaded areas are marine (modified after Gignoux, 1950). Possible communications between Paratethys and the Mediterranean are (1) Peri-Alpine Depression, (2) Istria, (3) Bosporus, (4) Caucasus.

The change from normal marine to an evaporiteforming condition was a sudden event! Yet the paleobotanical record gives no evidence of an abrupt change in climate. Benda (1973) summarized the evidence from Turkey, Greece, and Italy and stated that 'the most remarkable climatic changes to a drier and cooler climate must have taken place before the Tortonian or in the transitional interval between Serravalian and Tortonian.' In fact, even this change must have been a continuation of the general trend that had been in evidence ever since the Burdigalian, when the Mediterranean was first cut off from the Indian Ocean. Benda further remarked that his pollen evidence showed little climatic variation 'since early Tortonian and during the whole Messinian.' This conclusion is confirmed by Bertolani-Marchetti and Accorsi's (this volume) studies of Leg $42 \mathrm{~A}$ core material. They found a cooler and drier pollen assemblage, similar to that of the Messinian, in the latest Tortonian. Thus we cannot interpret the change from normal marine to evaporative conditions as a response to a drastic change in climate; the change had to be related to a final closure of the openings at the west sometime during the Messinian ${ }^{12}$. With the isolation and its hydrographic deficit the salinity crisis of the Mediterranean became finally inescapable.

We have, unfortunately, no record of the onset of the salinity crisis from the deep-sea cores. The contact between the restricted marine Messinian and the open

\footnotetext{
${ }^{12}$ One of the authors $(\mathrm{CM})$ believes that the Betic Strait was never completely closed, citing the evidence of the apparently continuous upper Miocene sequence there described by Montenat (1973). The question was debated heatedly during the Utrecht Symposium. Several of the co-authors (e.g., KJH, MBC) questioned whether Montenat was able to discern obscure disconformities of the Betic Pliocene-Miocene sequence.
}

marine Serravallian sediments in Hole 372 is a disconformity, representing a stratigraphic hiatus of 6 million years (Figure 5). That we failed to obtain such a record is accountable by the fact that the planning strategy required that drill sites be placed where the thick lower, salt-bearing lower evaporites are absent, so as to enable the drill string from Glomar Challenger to penetrate sediments older than the Mediterranean Evaporite. For this reason, we have to rely on land records for our knowledge, and for our future investigations, of the critical time interval when the salinity crisis first began (See Sturani, in press; Cita et al., this volume).

\section{THE GENESIS OF UPPER EVAPORITE}

\section{Division of the Mediterranean Evaporite Formation}

Seismic records suggested a twofold division of the Mediterranean Evaporite (See Figure 9 and Montadert et al., this volume).

1) An Upper Evaporite sequence, with numerous reflectors, up to several hundred meters thick, and consisting of dolomite, gypsum, anhydrite, and some salts.

2) The Main Salt sequence, seismically homogeneous, up to a thousand meters thick or more, together with a lower sequence of evaporites with several reflectors.

The distribution of the Main Salt unit is restricted to the more central part of each of the Mediterranean basins. The distribution of the Upper Evaporite unit is, however, much more extensive. The top of the unit, represented by the M-reflector, has been recognized on the seismic record throughout the Mediterranean (Ryan et al., 1971; Wong and Zarudsky, 1969). The relief of this reflector closely simulates the relief of the present submarine topography, indicating that the 
$1000 \mathrm{~m}$

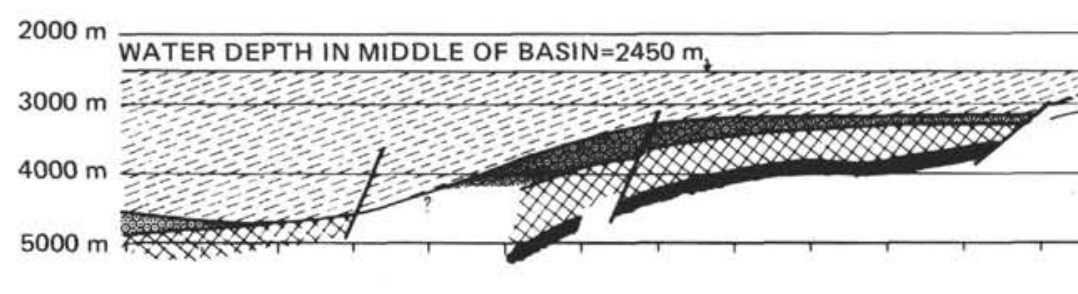

Plio-Quaternary

Figure 9. Twofold subdivision of the Mediterranean Evaporite. Note that the Upper Evaporite extends further toward the basin edge than the Lower Evaporite, which includes the main salt deposit. (a) Ligurian Sea near the northwestern corner of the Balearic Basin. The lower evaporite pinches out and the Pliocene/ Quaternary sediments thicken toward the Rhone submarine fan area to the northwest. (b) South Balearic Abyssal Plain near Site 371 (location of which is indicated by vertical arrow). Note that both the upper and lower evaporite pinch out toward the top of the submarine high. The lower evaporite (Main Salt) is restricted to the more basinal position under the abyssal plain.

(NW) Water Depth 2750 m

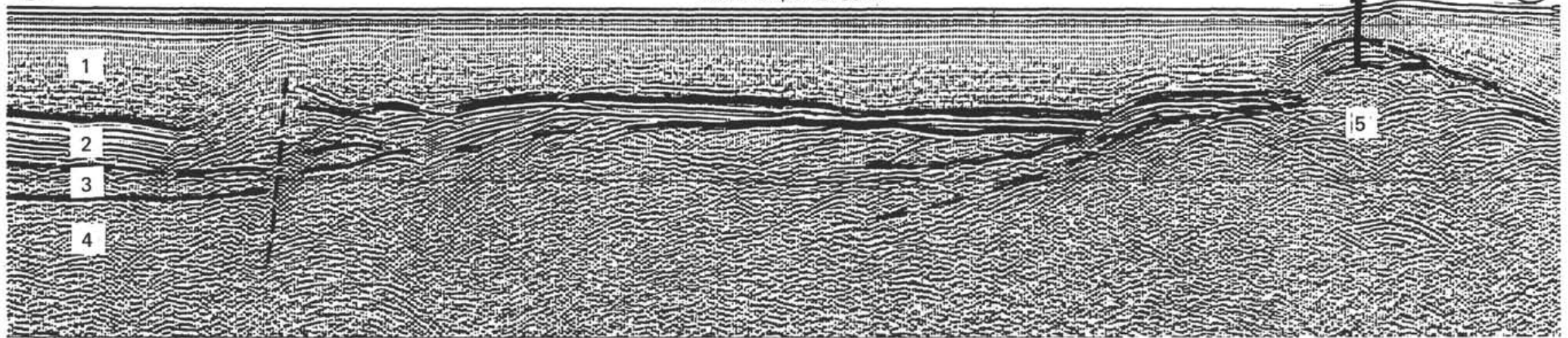

$$
\begin{aligned}
& \text { 1. Plio-Quaternary Sequence } \\
& \text { 2: Upper Evaporite Series }
\end{aligned}
$$



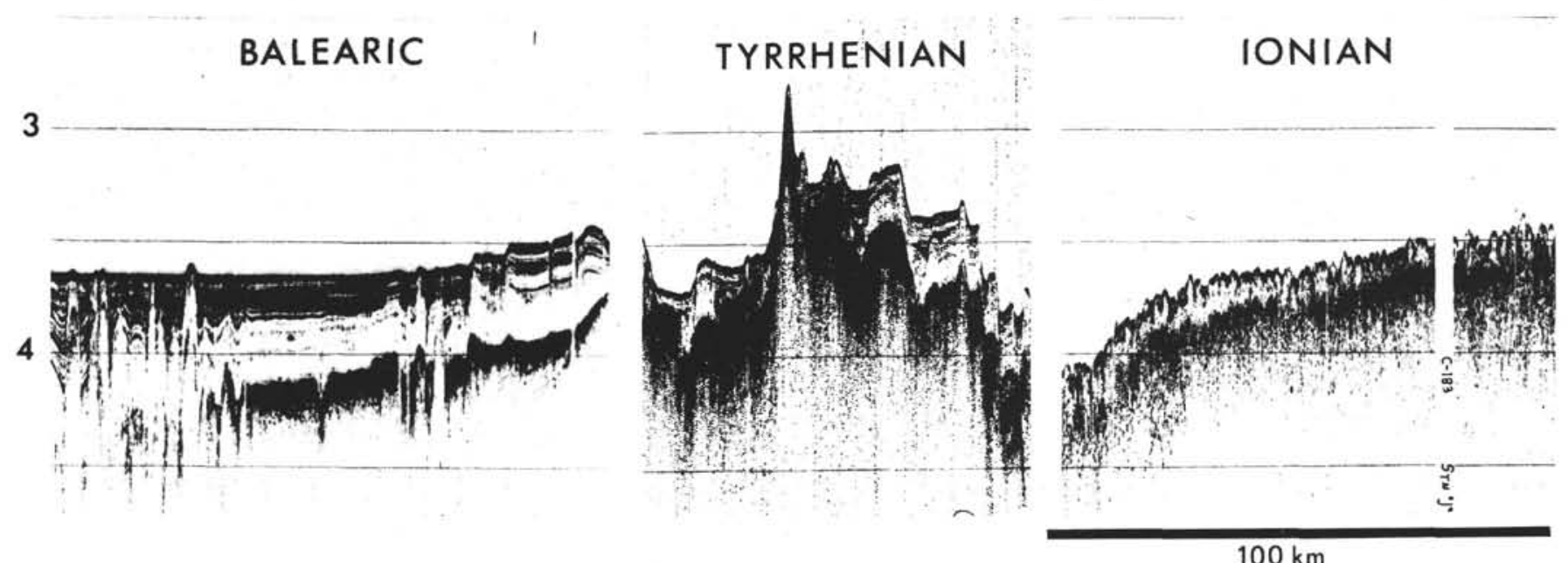

Figure 10. M-reflector, top of the Mediterranean evaporite (from Hs̈̈ et al., 1973). Vertical scale is in seconds (two-way time); vertical exaggeration is 55:1.

Messinian bottom configuration was not much different from that of today (Figure 10$)^{13}$. The parallelism of the M-reflector to the modern sea floor is particularly impressive in the Tyrrhenian Basin with its numerous seamounts and other rugged relief. Where the lower unit is absent, the Upper Evaporite overlies the preMessinian sediments unconformably, as we proved by drilling Site 372 on the Balearic margin (Figure 2) and Site 375 on the Florence Rise (Figure 6).

A similar twofold division has been recognized in the Messinian salt basins of Sicily (Figure 11). Decima and Wezel (1973) suggested intra-Messinian tectonic deformation. Field observations by some of us during the 1975 Erice Seminar at Eraclea Minoa near Agrigento showed that the intra-Messinian deformation was, at least in part, gravitational in response to widespread collapse associated with extensive salt dissolution.

The Sicily salt basins during the Miocene were probably some of the deeper Mediterranean basins, they had no drainage outlet so that halite and potash salts were deposited from the last bitterns. Other pericontinental evaporite basins such as those in Piedmont, in the peri-Adriatic and in Africa are not saliferous; they were relatively shallow and probably had an exit to deeper basins. The evaporite beds in those basins

\footnotetext{
${ }^{13}$ The statement that the Messinian Mediterranean "was not much different from that of today" seems to be a source of misunderstanding. We are quite aware of the many significant paleogeographic changes since the Messinian. Marginal areas or peri-continental basins around the Mediterranean have been severely deformed. The Tyrrhenian and the Aegean basins subsided in response to back-arc tectonic activities. Finally, there was isostatic subsidence of the basin floor everywhere as a consequence of the flooding of previously desiccated basins. It should be pointed out that we do not advocate a suspension of tectonic activities since the end of the Messinian. We do, however, believe the evidence that the oceanic crust under the Mediterranean was largely in existence long before the salinity crisis. The Balearic, the Tyrrhenian, the Ionian, and the Levantine basins were deep basins for open marine hemipelagic sedimentation prior to their desiccation and their resubmergence.
}

are mainly gypsum (Drooger et al., 1973; also Messinian Seminar, 1975, see Kidd, 1976), and the Messinian evaporites there cannot be subjected to a twofold division. Instead the sections are characterized by cyclic deposition, with the cycles repeated from several to 13 or 14 times (Vai and Ricci Lucchi, 1976). The correlation of sequences in peri-continental basins, with the Sicilian or the submarine sections is not certain as will be discussed later.

The Mediterranean evaporites sampled by the Deep Sea Drilling Project during its two cruises belong exclusively to the Upper Evaporite unit. Contributions to the understanding of the environment of evaporitedeposition during the Messinian from drilling are thus limited to interpretations of the Upper Evaporite. Its genesis will be discussed first, followed later by some comments on the origin of the Main Salt and of the cyclically deposited Messinian sections on land.

\section{Subdivision of the Upper Evaporite Unit}

We have penetrated the edges of the Upper Evaporite at Site 372 and at Site $\mathbf{3 7 5}$, where its thickness is 50 meters or less. Under the central abyssal plains of the Mediterranean basins, the Upper Evaporite reached maximum thicknesses of several hundred meters. Under the Messinian Abyssal Plain (Site 374) and on the edge of the Antalya Basin (Site 376) we explored the central, saliferous facies, but we penetrated only to some 80 and 160 meters, respectively, below the base of the Pliocene, and thus were unable to obtain a complete record. The Upper Evaporite has also been sampled at DSDP Sites 121, 122, 124, 125, $129,132,134,371$, and 378 . The cores from these strategically placed sites provided considerable information on the sedimentary environment and facies distribution of the Upper Evaporite unit.

If we define the Upper Evaporite unit as the sediments below the base of Pliocene and above the Main Salt, this upper unit can again be given a twofold subdivision (Figure 12). 


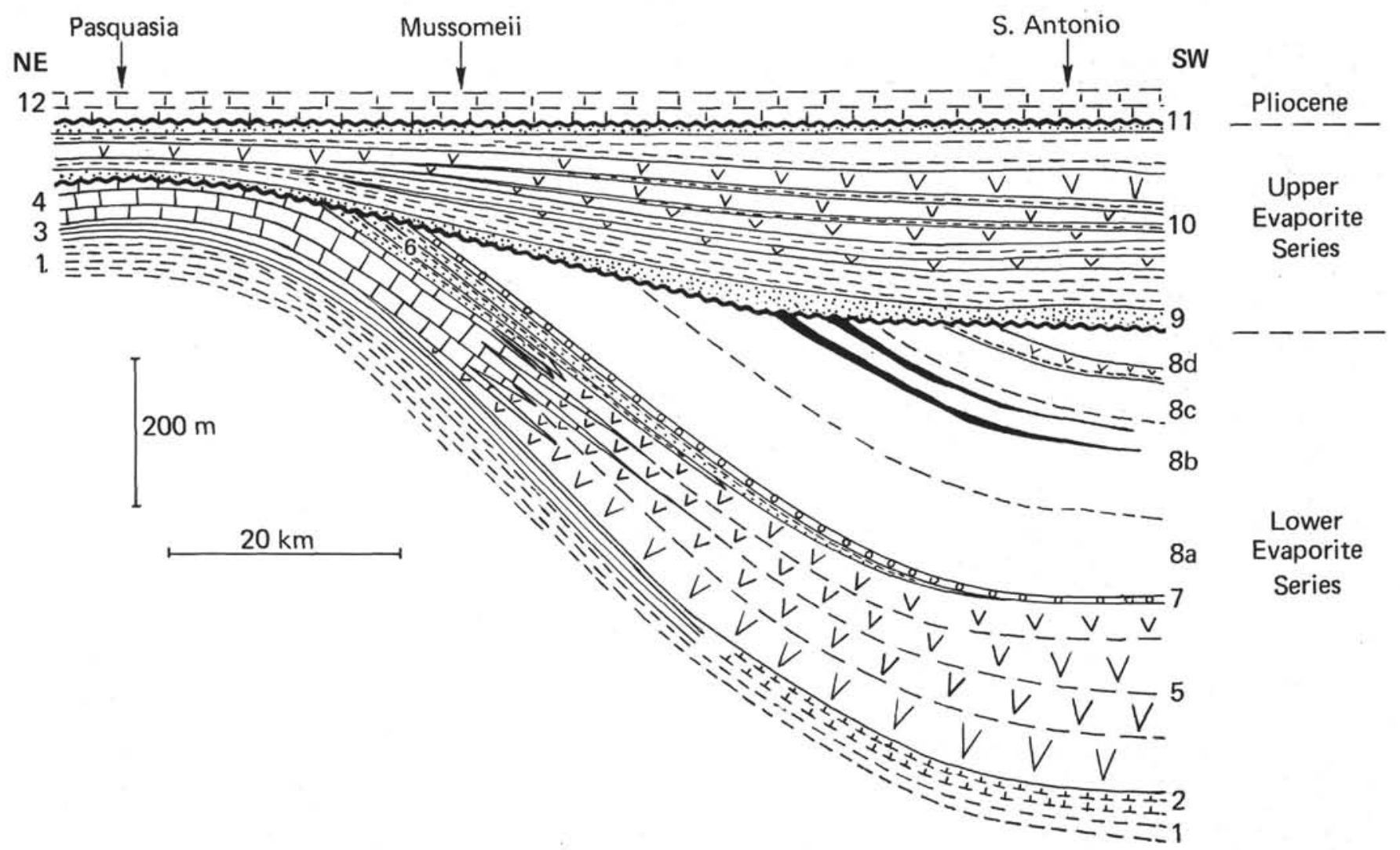

Figure 11. Twofold division of the Mediterranean Evaporite in Sicily (from Decima and Wezel, 1973). NE-SW stratigraphic section of Solfifera Series along the line approximately correspondent to the Cattolica Basin axis. The lower group of the Solfifera Series (No. 1-8): (1) lower Messinian marly clay, (2) whitish marls, (3) Tripoli Formation, (4) basal limestone, (5) Cattolica gypsum beds, (6) gypsum turbidites, (7) marly anhydritic basal breccia, (8a-8d) halite ("Zone A") and potash ("Zone B") beds with intercalations of potash salts ("Zone C") and basal dark anhydritic marl ("Zone D"). The upper group of the Solfifera Series (No. 9-11): (9) transgressive gypsum-arentite, (10) Pasquasia gypsum beds, (11) Arenazzolo. The Trubi Formation: No. 12.

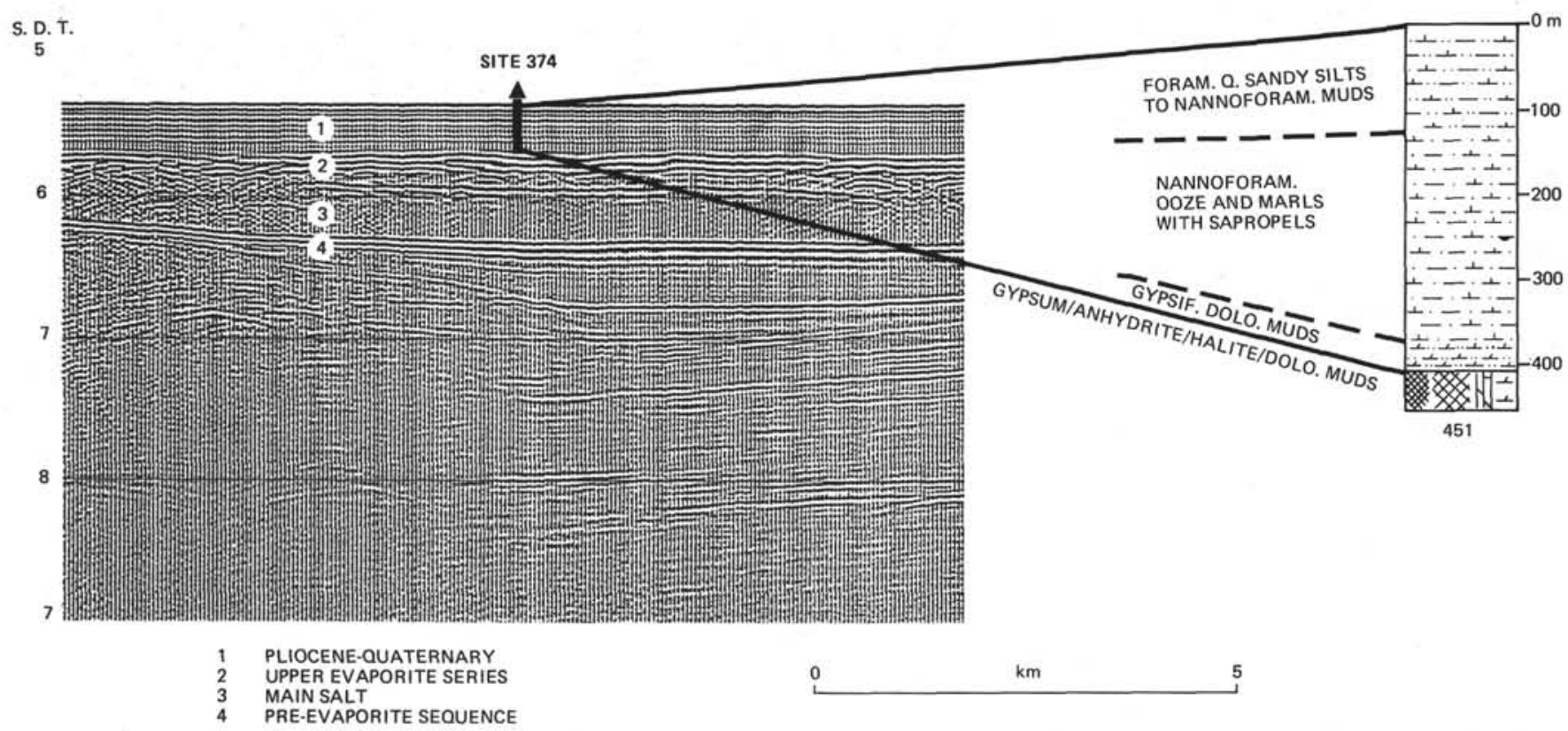

Figure 12. Upper Evaporite from Site 374. Note that we did not reach the base of the evaporitic subdivision. 


\section{1) “Lago Mare," or nonevaporitic, upper subdivi-} sion

2) Evaporitic subdivision including cyclically deposited gypsum, marls, and salts.

A complete record of the "Lago Mare" deposits was obtained in Holes 374 and 376; its significance will be discussed in the next section. We shall limit our discussions here mainly to the genesis of the evaporitic subdivision of the Upper Evaporite. Please note that we failed to penetrate to the bottom of this subdivision; the portion of the Upper Evaporite not reached by drilling probably also consists of cyclically deposited sulfates and carbonates plus salts as described here.

\section{Saline Zonation}

Drilling confirmed the "bulls eye" pattern of saline zonation of this evaporitic subdivision which was suspected from seismic evidence (Figure 13). The four saline zones and their distribution are:

Dolomite only at Site 121

Dolomite and gypsum (and/or anhydrite) at Sites 124, 125, 132, 134, 371, 372, 375, 378.

Dolomite and gypsum (and/or anhydrite) and halite at Sites 134 and 376.

Dolomite and gypsum (and/or anhydrite) and halite and potash salts at Site 374.

Through drilling sites near topographic prominences, namely Sites 122, 133, and 371, Messinian terrigenous clastics have been cored in place of, or in addition to, evaporite minerals. Messinian sediments are absent on or near seamounts or tilted basement highs bounding abyssal plains, such as at Sites 123, 129,134 , and 373 .

Three different models have been proposed to explain zonation of saline minerals.

1) Brine-refluxing models: Several variations have been proposed on the theme of brine refluxing. The basin may either be shallow (King, 1947; Scruton, 1953) or deep (Schmalz, 1970). The main suppositions here are that an opening to the world ocean existed, and the brine level within the basin was equal to sea level so as to receive marine waters from, and to return brines back to the open sea. The saline zonation resulting from such a process would give a tear-drop pattern (Figure 14, see also discussions in Schmalz, 1970: Hsü, 1972), but not the observed pattern.

2) Separation-basins model: The model assumes the existence of a series of evaporite-depositing basins each, except the last draining into a lower one (Branson, 1915). This originally purely hypothetical idea was probably inspired by the processes of making artificial salt. In each basin, the evaporite deposit could be monomineralic, with the evaporative carbonate deposited in the highest, sulfate in the next, halite in the ensuing, and potash in the lowest basin.

3) Progressive-desiccation model: This model postulates gradual lowering of brine level in a completely isolated basin. With the gradual concentration of the brine, minerals of increasingly greater solubility would be successively precipitated. This model was originally elaborated to explain the origin of saline zonation of playa lakes (Hunt, 1960; Jones, 1961). The distribution of saline minerals in any isolated basin being progressively desiccated should have a "bull's eye" pattern (Schmalz, 1970; Hsü, 1972).

The lack of a tear-drop pattern for the saline zonation of the Messinian Upper Evaporite Unit, as was previously discussed by Hsü et al. (1973a, b), argues against a model of brine-refluxing. Also recall that the reflux model was proposed originally to explain the occurrence of monomineralic evaporites such as thick sulfate deposits without halite, or thick halite deposits with potash salts. The problem of segregation of the Messinian evaporite minerals can be explained by the separate-basin model. Paratethys in eastern Europe, peri-continental basins on the shelf margin of the Mediterranean, and the deep Mediterranean basins may constitute a sequence of separate basins as envisioned by Branson (1915). For example, Messinian evaporitic carbonates were deposited in the Black Sea (Hsü, 1977), which was one of the Paratethyan basins draining into the Mediterranean. Gypsum was being deposited in the Periadriatic Basin and in several other peri-continental basins. Halite and potash salts were deposited only in those deep basins which had no outlet for the last bitterns! Furthermore, there is the additional complication of detrital-evaporites and of recycling! Hardie and Eugster (1971), for example, found extensive detrital gypsum deposits in Sicily. Decima (1975) and Kuehn and Hsu (this volume) noted that continuous sequences of halite without potash salts are recycled deposits, whereas the halites derived from evaporation of seawater are interbedded with more soluble salts. Thus we do not have to depend upon the brine-refluxing hypothesis to come up with a rational explanation for the segregation or the association of the Messinian evaporite minerals.

The pattern of saline zonation was already apparent after the Leg 13 drilling. We were thus able to predict the occurrence of potash salts under the central Messinian Abyssal Plain. Leg 42A drilling results elsewhere are also consistent with the postulate of a "bull's eye" distribution of evaporites within each of the Mediterranean deep basins. This fact is considered one of the strongest arguments for the isolation and progressive desiccation of the various basins (Hsü et al., 1973b; Drooger, 1973).

The "bull's eye" pattern of facies distribution gives no indication of basin depth; the evaporative residue may have been rimming a deep saucer or a shallow salt pan. The evidence that the Messinian Mediterranean salt basins were deep depressions has been provided by considerations such as those discussed in the preceding section. The pattern of facies distribution also cannot indicate brine depth. Brine depths in isolated deep basins can be considerable. The present Dead Sea, for example, has a water level of 400 meters below the sea level, but its brine depth is still another 400 meters; it is not exactly a shallow salt pan! The water depth in the Mediterranean basins undergoing desiccation should have been quite variable. Theoretically gypsum deposition in a basin 2000 meters deep could start when half of the original seawater was 


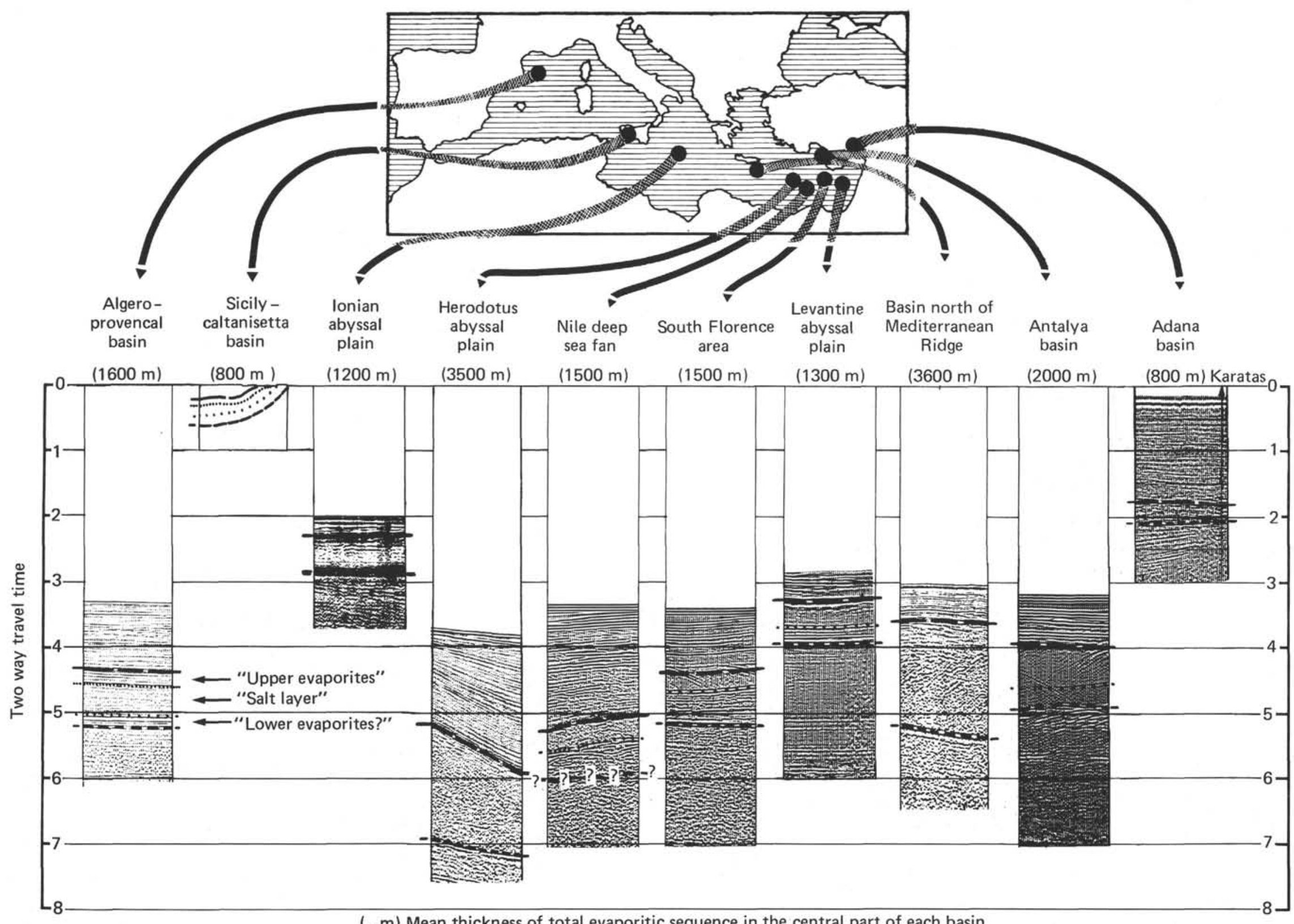

( m) Mean thickness of total evaporitic sequence in the central part of each basin 

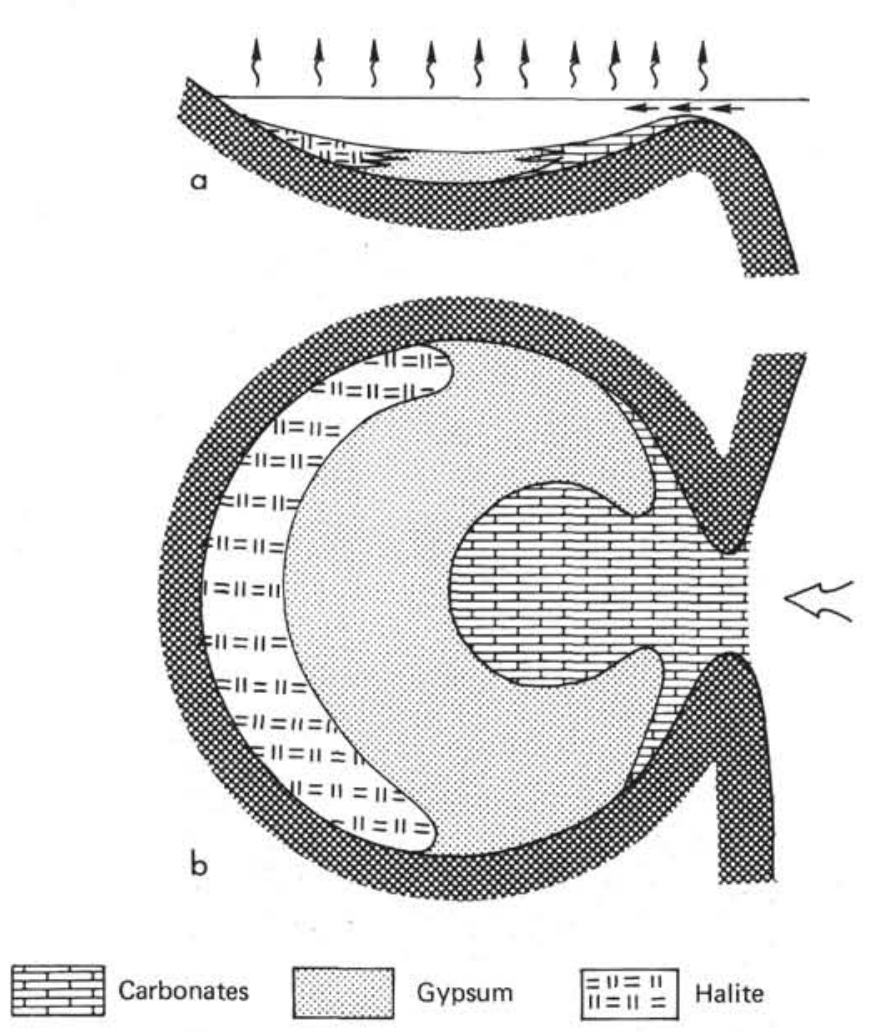

Figure 14. Tear-drop pattern (from Schmalz, 1970). (a) cross-section, (b) plan view.

removed by evaporation, or when the water depth was still 1000 meters. At more advanced stages of desiccation, the depth may have been only a few meters, or completely dry. Thus the evidence of water depth of evaporite deposition must be sought from the evaporites themselves.

\section{Cyclic Deposition}

Those who have been shipboard scientists on Glomar Challenger are well aware of the problem of obtaining a continuous core section, especially if the section consists of alternating hard and soft layers. Where coring is random and recovery poor, one rarely notices rhythmic changes. It was, therefore, not surprising that Leg 13 scientists recognized cyclic sedimentation only when a 3-meter-plus continuous section of evaporite core from Site 124 was patched together long after the cruise. The four members of a cycle are from bottom to top: (1) laminated carbonates; $(2)$ interlaminated dolomite and sulfate; (3) stromatolitic carbonate and sulfate; and (4) nodular anhydrite (Hsü et al., 1973a).

A similar pattern of cyclic sedimentation of the Upper Evaporite was recognized in Hole 374. An idealized cycle is portrayed in Figure 15. The descriptions and interpretations of the three members from $\mathrm{A}$ at bottom to $\mathrm{C}$ at top are based upon detailed sedimentological studies by Garrison et al. (this volume).

A Member: The major lithology is rich in organic matter, dolomitic mudstone, homogeneous, or finely laminated (comparable to Member I of a Site 124 cycle). Gypsum crystals are commonly scattered

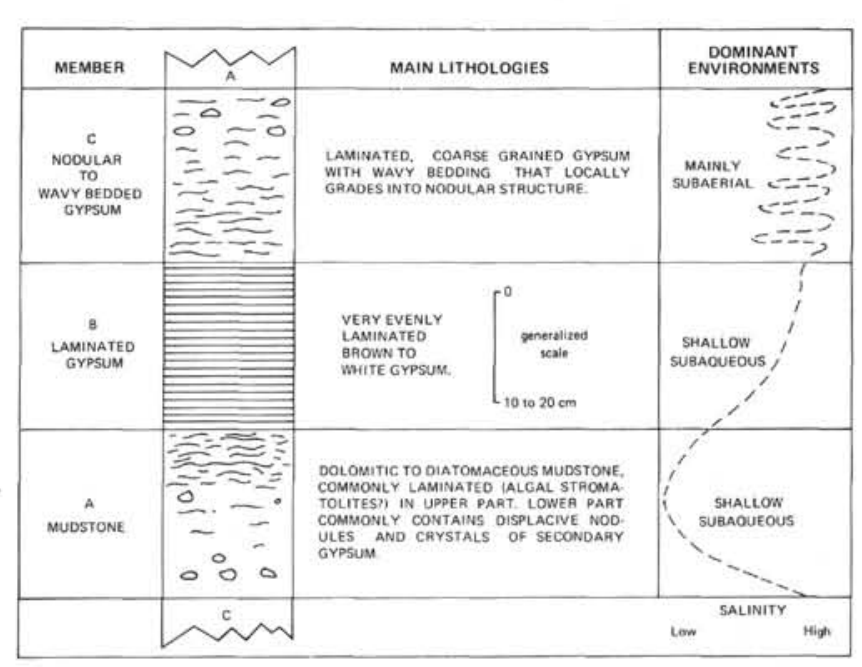

Figure 15. Cyclic sedimentation at Site 374 (from Garrison et al., this volume).

throughout the mudstones and are seen to disrupt laminations. The mudstones were interpreted to be the product of shallow, subaqueous deposition, and the gypsum crystals were secondary growths that occurred during subaerial diagenesis.

B Member: The major lithology is a brown gypsum with blotches and with even and generally silty laminations (comparable to Members II and III of a Site 124 cycle). This is the type of gypsum called "balatino" by workers in Sicily. The laminae are defined by very thin seams of organic matter (possibly algal coatings). The gypsum was interpreted as shallow subaqueous sediment, deposited probably within the photic zone, before undergoing extensive recrystallization.

C Member: The dominant lithology is nodular gypsum (comparable to Member IV of a Site 124 cycle). Member $\mathrm{C}$ sediments include small selenitic crystals and carbonate muds deposited in shallow subaqueous conditions. The sediments were displaced and replaced by nodular anhydrite, which in turn was changed to nodular gypsum in a later diagenesis.

In a 20-meter section from Hole 374 (Cores 16-20), some five cycles were recognized. They resemble Messinian cycles described from Sicily (Heimann and Mascle, 1974; Schreiber et al., 1976).

Garrison et al. (this volume) interpreted a cycle as indicative of a general lowering of water level, of increasing salinity, and of increasing degree of subaerial exposure. The overall pattern, therefore, is one of submergence-desiccation, as a result of flooding and subsequent evaporation. The range of features in these cycles resembles very closely those found in Holocene tidal flat cycles of arid regions such as those beneath the sabkhas of the Trucial Coast (Butler, 1970). In the tideless sea of a desiccating Mediterranean, the cycles should not represent tidal fluctuations, but climatic fluctuations which raise or lower water level over rather short time spans. The possibility that such slight fluctuations of water level could produce these drastic sedimentological changes is further evidence that the water depth was very slight and the basin floor was extremely flat. 
The fact that nodular anhydrite (or gypsum) has been found in the basinal facies of evaporitic deposits and the unwillingness to entertain the working hypothesis that a basin could be occasionally desiccated led numerous workers to question the sedimentological significance of this feature (e.g., Kendall, 1974; Dean et al., 1975). However, the interpretation of shallowwater or subaerial genesis of the Upper Evaporite has not been based upon comparative sedimentology. The more critical evidence is paleoecological: shallow-water diatoms, and algal stromatolites, both of which are most reliable environmental indicators, have been found in Leg 13 cores (Hajos, 1973; Schreiber, 1973). Diatoms, which lived in water depths less than 20 meters, and algal filaments indicate growth in the photic zone were again found in Leg $42 \mathrm{~A}$ cores. (Schrader and Gersonde, this volume; Awramik, this volume). Their presence in the cyclically deposited sequence of Site 374 is an unquestionable confirmation of the environmental interpretations of Garrison et al., this volume, who based their conclusions upon principles of comparative sedimentology. The Upper Evaporite cores from other Leg $42 \mathrm{~A}$ sites are less well sampled. However, sedimentological studies of those samples available have led to the same conclusion; the evaporitic sediments were deposited in shallow waters and were diagenetically changed in subaerial environments (see Site Reports, Chapters 2, 3, 6, 8).

The occurrence of shallow-water sediments and products of subaerial diagenesis in basins which had held thousands of meters of marine waters implies either uplift or desiccation. There is neither evidence nor a suitable mechanism for the postulate of a basinwide uplift during the Messinian to change suddenly a series of deep basins into a broad, flat shelf sea. Calculations, however, have shown that the waters in a Mediterranean about as deep as today could be evaporated dry within 1000 years or so, if and when it was completely isolated (Hsü et al., 1973a). It is this line of reasoning which led us to adopt the deep-desiccated basin model to explain the genesis of the Mediterranean Evaporite.

\section{Origin of Salts in the Upper Evaporite Member}

The deep-sea drilling holes failed to penetrate into the Main Salt unit. The halite and potash salts encountered in Holes 134, 374, and 376 all belong to the Upper Evaporite (Figure 16).

Sedimentological evidence indicated that the halite from Site 134 was precipitated from a shallow saline pool (Hsü et al., 1973a). This conclusion was subsequently confirmed by the "bromine profile" of halite;
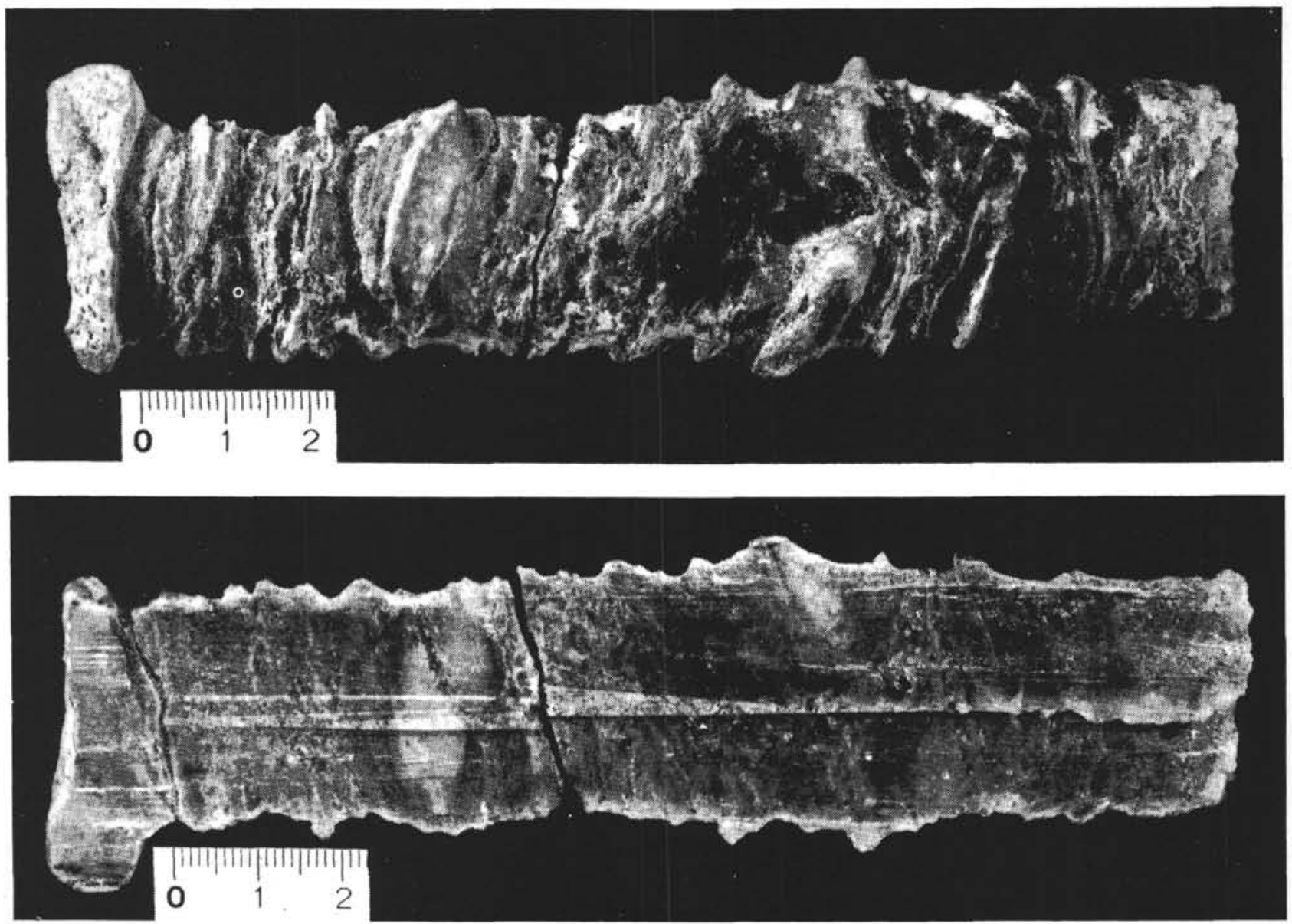

Figure 16. Halite and potash salts, Site 374. (from Kuehn and Ḧ̈u, this volume). 
the bromine composition changed greatly from one horizon to another, as one would expect from salt deposited in a shallow pool (Kuehn and Hsü, 1973).

The bromine content of the Site 134 halite ranges from 140 to $254 \mathrm{ppm}$, while that of Site 374 , which is associated with potash salts, ranges from 150 to 840 ppm (Kuehn and Hsü, this volume). The high bromine content suggests that the salts were deposited from a brine derived from the evaporation of seawater. In contrast the halite of Site 376 has a very low bromine content of only 20 to $30 \mathrm{ppm}$ (Kuehn and Hsü, this volume). It is very likely that this halite has been recycled, because secondary halite, deposited from a brine which has derived its $\mathrm{NaCl}$ from the solution of primary halite, has little bromine.

It is interesting to note that the last salt has not been recycled in the Balearic and Ionian basins, whereas that of the Antalya Basin has been recycled. Apparently the margin of the latter was exposed, and the primary halite on the lower flank of the Florence Rise was dissolved by streams and redeposited in a brine pool occupying only the more central part of the Antalya Basin.

\section{Marine Incursions}

Marine fossil assemblages are present in the marls overlying, or interbedded with, evaporite layers in the western Mediterranean holes (124, 132, 134, and 372). The foraminifer faunas in these marls are, as a rule, dwarfed, indicating that marine organisms lived in the Mediterranean during the Messinian, at times when the desiccated basin was again completely, or partially, filled with seawater. The ecologic conditions were, however, unfavorable. The faunal abundance, the faunal diversity, and the degree of dwarfness are different at different levels, suggesting variable degrees of stress (Cita et al., this volume). In Hole 372, for example, a rich and diversified Messinian fauna is present in Sample 372-9-1, $130 \mathrm{~cm}$, where keeled Glorobotalias are present. Similar dwarfed foraminifer faunas, made up of planktonic species only and less diversified, are present in gypsiferous marls intercalated between finely laminated gypsum (Sections 3726-1 and 372-5-1). The uppermost Messinian sediments (Core 4, Section 1) in this hole contain again a rather diverse fauna of planktonic and benthic foraminifers. The conditions were inhospitable even then as suggested by the unusually high proportion of Bolivina and Cassidulina in the benthic population. The presence of deep-water species of Cibicides indicates that the water depth of this latest Messinian sea was at least as deep as lower epibathyal (Cita et al., this volume).

To summarize we conclude that the western Mediterranean basins were covered by marine waters represented repeatedly during the time span by the Upper Evaporite deposition. Probably the marine incursions managed to spill over the Sicilian Strait, a few times at least, as sediments with marine fossils are also present in the largely "Lago Mare" sequence of Sites 374 and 376. However, the possibility cannot be ruled out that the marine incursions to the eastern Mediterranean originated from the Indian Ocean.

That there should have been periodic seawater influx alternating with episodes of evaporite-deposition is not surprising. The volume of the Mediterranean salts necessitates repeated incursions to transport enough ions across for salt-deposition (HSü et al., 1973a, p. 1215; Hsü et al., 1973b). The total water influx of each marine incursion into a desiccated Mediterranean had to be greater than the basin volume, because the basin could not have been filled instantly; an excess was needed to offset evaporative losses during the transient stage of basin infill. If it took a few thousand years before the Mediterranean could be filled up, the evaporative losses during those years would amount to one or two times the basin volume. Using this line of reasoning, Hsü et al. (1973a, p. 1216) suggested that 11 interludes of infill would have been sufficient to account for the transport of ions from the Atlantic and thus for the Messinian salt deposition in the Mediterranean. If the rate of infill was much slower, or if a transient state of Gibraltar saltwater-fall should persist for 50 or a 100,000 years, much of the Messinian salt would be brought in by one single episode of steady seawater influx. Vai and Ricci Lucchi recognized some 13 to 14 cycles of marine flooding from their studies of the Apennine evaporites, but it was questionable if seawater was filled to the brim for each or any of those episodes. The few marine episodes registered by the Hole 372 cores may represent the times when the Mediterranean water level was up to about the same level as that of the worldwide sea level; otherwise the salinity of the Mediterranean would have been intolerably high for marine organisms, when there was no exchange between the Mediterranean and the open ocean to compensate for evaporitic excesses. On the other hand, the submergence phase of the Ionian flooding cycles (as recorded by Hole 374 cores) was neither fully marine nor demonstrably very deep. To conclude, it seems that there have been a few or several marine floodings during the time of Upper Evaporite deposition; the relatively thin salt deposits in the Upper Member might well be residues of those floods. On the other hand, as will be discussed later, the origin of the Main Salt body in the Lower Evaporite may be different; the record of an apparently uninterrupted sedimentation in Sicily (Decima, 1975) seems to favor an alternative origin for the main salt deposition such as one period of steady seawater influx.

\section{THE MESSINIAN SALINITY CRISIS}

Since drill cores yielded information only on the Upper Evaporite, we depend on land sections for an overview of the Messinian salinity crisis. Many papers dealing with the question of the Messinian crisis on land were presented during a 1973 seminar at Utrecht (Drooger et al., 1973) and a 1975 seminar at Erice, Sicily (Kidd, 1976). The onset of the salinity crisis is commonly indicated by the contact of Calcare di base 
on "Tripoli," signifying a very rapid change from a bathyal environment of hemipelagic sedimentation, to a shallow, or subaerial environment of carbonate deposition and diagenesis (see summary by Cita et al., this volume).

The history of the early evaporite deposition can be deciphered by reference to the section of the Cattolica basin, Sicily (see Decima and Wezel, 1973). The Lower Evaporite sequence there lies above the Tripoli Formation and includes (1) Calcare di base (2) Catolica Gypsum, (3) Clastic Gypsum beds, (4) halite and potash salts. The Lower Evaporite is overlain unconformably by an Upper Evaporite of gypsum and marls. The stratigraphy is shown diagramatically in Figure 11.

The halite and potash salts are on the average 400 to 500 meters thick. Decima (1975) divided a 330 meter section of salts at Porto Empedocle into four units. Unit $\mathrm{A}$ is a halite with laminae of anhydrite and is 108 meters thick. The bromine content is in the range of $400 \mathrm{ppm}$. Unit B is well laminated halite, kainite, polyhalite, and anhydrite, and is 115 meters thick. The bromine content ranges from 200 to 250 $\mathrm{ppm}$ except for the uppermost pure halite which has about $100 \mathrm{ppm} \mathrm{Br}$. Units $\mathrm{C}$ and D overlie the lower salts unconformably. They are 107 meters thick and consist of halite, with anhydrite and anhydritic shales. The halite in these upper units has only traces of bromine (10 ppm or less).

The lower salts with their high $\mathrm{Br}$ were precipitated from brines derived from evaporated seawater. In contrast the upper salts were recycled. Sedimentological studies by Schreiber et al. (1976) suggested that the halite hopper crystals in the lower part of Unit A and in the upper part of Unit D were deposited in shallow salina environments. On the other hand, the welllaminated Unit B, with sequences of cyclic lamination that can be correlated for long distances, were precipitated in a relatively deep subaqueous environment. Schreiber et al. (1976) estimated a brine-depth of several hundred meters.

The peri-Adriatic Messinian sections of the northern Apennines do not lend themselves to a twofold subdivision into lower and upper members. Above the Calcare di base are massive gypsum beds constituting the Gessoso-solfifera Formation. Still higher is a postevaporitic, clastic Colombacci Formation, which is equivalent to the post-evaporitic "Lago Mare" deposits of the eastern Mediterranean holes.

Sedimentological investigations by Vai and Ricci Lucchi (1977) on the Messinian of the Vena del Gesso Basin revealed that the Gessoso-solfifera is characterized by cyclic sedimentation. These cycles of flooding and exposure are different in detail, but similar in origin to those at Hole 374 described by Garrison et al. (this volume). Each cycle was initiated with a marine flooding, followed by subaerial exposure, a consequence of evaporative-drawdown of the water level within the basin. Counting of the cycles indicates that the Vena del Gesso Basin was inundated some 13 or 14 times during the Messinian.
The Sicilian and the Apennine sections seem to provide somewhat conflicting evidence with respect to the supply of brines for salt deposition. The stratigraphy of the Cattolica basin, Sicily, suggests that the main halite body was deposited during the early Messinian, and that much of the salt was precipitated from a deep brine pool. The supply of brines would depend upon a steady influx of seawater. The water level of the Mediterranean basins containing haliteprecipitating brines was probably lower than that of the Atlantic to permit a continuous inflow of saltwater, but sufficiently high to permit the brines to spill over from one basin to another. The stratigraphy of the Apennines, on the other hand, emphasizes cyclic sedimentation. There, the brines were brought in by periodic seawater influx, namely by repeated inundations.

We do not know which, if any, cycle of gypsum deposition in Vena del Gesso was coeval with the main halite deposition (Unit B) at Porto Empedocle. In fact if the sill of the former was higher than the brine level of Mediterranean salt basins, the time of main halite deposition might be represented by an unconformable interval of subaerial exposure in this peri-continental basin.

A comparison of the submarine Messinian with the land sections suggests a two-stage evolution for the Messinian salinity crisis. After an initial desiccation or partial desiccation, which led to the formation of the widespread Calcare di base the Lower Evaporite was precipitated, when the supply of the brines was sufficiently continuous, and lead to the accumulation of thick halite and potash salt deposits in the deepest of the Mediterranean basins. Towards the end of the Main Halite deposition, the supply of brine was probably stopped by complete isolation from the Atlantic. The brine level was relentlessly drawn down because of evaporative loss. Large areas on the periphery of the salt basins were exposed. Waters from the continent or from local precipitation formed salt creeks, eroding primary salt (e.g., Units A and B , Porto Empedocle), and depositing secondary salts (e.g., Units C and D) in the center of the salt basins.

This period of desiccation was represented by the widespread unconformity separating the Lower and the Upper Evaporite units. Rivers cut canyons on the margins of the continents and some of these canyons were eventually floored by the Upper Evaporite deposits (Montadert et al., this volume).

The erosional event was terminated by a new inundation of the Mediterranean, when it was probably again filled to the brim. The lowest marine marls of Messinian age at Site 372 (Core 9, Section 2) are the first sediments above the unconformity and they may have been deposited during this intra-Messinian flooding. The subsequent history of the Upper Evaporite sedimentation was probably characterized by periodic influx. Each marine inundation may have permitted the accumulation of dozens of meters of salt accumulation in the central parts of the Mediterranean basins, as a result of their partial or total desiccation. The upper 
Messinian Mediterranean was floored by a series of desert basins, some with salt lakes, prior to inundation by the "Lago Mare."

The history of the peripheral basins was different: Except for a few (such as the Volterra Basin in Tuscany) the bitterns of these basins were drained into the Mediterranean depressions. No salts were deposited, and the Messinian record shows multiple cycles of flooding and desiccation, but no two-stage evolution of the crisis.

\section{LAGO MARE}

The geological record of the eastern Mediterranean sites revealed a drastic change in depositional environment during the latest Messinian before the Pliocene marine inundation. After the last salt deposition of the Upper Evaporite, the Ionian and Antalya basins were almost totally dried up. Slight changes in the water budget led to conditions of cyclic sedimentation. The isotopic evidence suggests a considerable supply of continental waters to these already desiccated basins (Pierre and Fontes, this volume; Ricchiuto and McKenzie, this volume; Cita et al., this volume). Probably little or no marine waters ever got into the eastern Mediterranean during this stage, for only gypsum, but no salts was deposited at the end of each desiccating cycle.

The very last Messinian sediments at Sites 374 and 376 are marls, deposited in a standing body of water. Both the Antalya and the Ionian basins remained under subaqueous conditions while the marls were being deposited. The depth may have been considerable, because both basins seemed to have remained under subaqueous conditions. If the water bodies had been very shallow, unavoidable variations of hydrographic budget however slight, would lead to cyclic sedimentation. Isotopic evidence indicates that the water was derived largely from a continental source, but had undergone considerable evaporative history resulting in differential enrichment of heavier isotopes (Pierre and Fontes, this volume; McKenzie and Ricchiuto, this volume; Cita et al., this volume). Site 376 samples contain an Ammonia becarrii-Cyprideis pannonica fauna, indicative of a euryhaline environment (see Site 376 report, this volume; also Cita et al., this volume). This fauna is not found in the Messinian dolomitic marls of Site 374, where the bottom may have been too deep or too stagnant to permit population by this benthic fauna. The Cyprideis pannonica assemblage is a typical fauna of the Pannonian sediments of the Paratethys, which have been dated radiometrically to be 8 to 11 m.y. (Vass et al., 1975). The Messinian and Pannonian faunas are not coeval, but are facies equivalent. Shallow-water diatoms are present in Core 17 of Site 374. The floras were described as "limnic" or brackish (Schrader and Gersonde, this volume).

Some marine fossils are present in the marls. Some of us consider these occurrences allochthonous, having been reworked from older deposits (Cita et al., this volume). Others consider the occurrences as indicative of occasional spillover of marine waters into the eastern basins (see site reports 374 and $375 / 376$, this volume). This disagreement does not affect our main conclusion that most of the marls were deposited in a subaqueous, brackish environment.

The Cyprideis and other euryhaline faunas are present in numerous uppermost Messinian sections on land both east and west. Interpretations of these faunas led Ruggieri (1967) to conclude that the Mediterranean became gradually desalinified as in the presentday Caspian. These lakes of reduced salinity were referred to collectively as the "Lago Mare," an Italian translation of the French expression "lac mer" which refers to the system of the Neogene brackish lakes of the Paratethys region (see Figure 8, also Gignoux, 1950 ). We propose, however, that the term "Lago Mare" be used to designate the latest Messinian oligohaline environment, postdating evaporite deposition and predating Pliocene marine sedimentation (see Site 375/376 report, this volume and Cita et al., this volume), in order to distinguish it from "lac mer" which, strictly speaking, was a Paratethyan environment.

The change from salt precipitation in shallow salinas to deposition of marls in "Lago Mare" occurred within a very short period of the latest Messinian, probably in 100,000 years or less. The change implies a radical alteration of the hydrographic budget. The desiccation and salt-deposition required that the annual evaporative loss was considerably more than the annual supply of water from the rivers. The existence of brackish water lakes, on the other hand, implied the influx of fresh or brackish water in excess of evaporative loss.

Sudden changes from dry to wet climate are not uncommon, especially during the change from glacial to interglacial stages. Quaternary sediments of African lakes, for example, include interbedded sequences of playa-evaporite and subaqueously deposited muds (Stoffers, 1975). However, a sudden climatic change affecting the whole circum-Mediterranean region was an unlikely event, and we know of no paleobotanical evidence for any such drastic changes during the Messinian. We prefer, therefore, to entertain the alternative hypothesis that the environmental changes were the consequence of a reorganization of the drainage system. The sudden appearance of so much fresh or brackish water, together with a typical Paratethys fauna, in fact, indicates a sudden inundation of the desiccated Mediterranean by waters from Paratethys.

That such an invasion did take place has been speculated by biogeographers on the basis of the occurrence of relic Paratethys faunas (freshwater fish, mollusks, birds, etc.) in isolated areas of circumMediterranean land areas today (Stankovic, 1960; Vosus, personal communication). The evidence from Paratethys also indicated that it suddenly lost much of its waters to the Mediterranean in late Neogene. The widespread regression of the Paratethys was designated as "middle Pliocene" but estimated to have an absolute age of about 5 to 6 m.y. Jiricek (1975, p. 16) concluded that the regression was "caused by the 
migration of (Paratethys) waters into the dried-up bed of the Mediterranean." The Black Sea probably also was drained during that time. Partial emptying by drainage, and a subsequent evaporative excess resulting from the change in water-budget led to a considerable desiccation of this deep Paratethyan Basin and to the formation of evaporative carbonates (Hsü, in press).

We know little about the exact cause of the Paratethyan invasion. However, it is not difficult to visualize that headwater erosion of rivers draining into the Mediterranean may have acquired great erosive power during its low water stand so that they breached the divide and captured the Paratethyan drainage.

The route of the Paratethyan invasion is also uncertain. The most direct route through the Bosporus was probably not open. Nor do we have any evidence or a passage through the peri-Alpine depression or through Anatolia. Biogeographical analyses suggested that the exit of the Paratethyan drainage probably lay on the Adriatic coast. Interesting clues are provided by studies of the present-day relic faunas of the western Dinaric region, particularly those of Lake Ohrid on the border between Yugoslavia and Albania. The faunas are believed to be the living fossils of a Neogene thermophilic fauna of the circum-Mediterranean domain (Stankovic, 1960). That a Neogene connection from Paratethys to the Dinarides existed was indicated by the presence of a diatom flora in Lake Ohrid; the flora is typical of the Neogene of the Pannonian Basin. The connection may have threaded through from the Pannonian to the Valley of Nis to Metohia and Kosovo basins to Lake Ohrid (Figure 17). The Ohrid is draining into the Adriatic today and may have done so during the Messinian.

A Cyprideis fauna is present in the Messinian deposits of Thessalonika and on the Island of Crete (Sissingh, 1976). The fauna is believed to have been

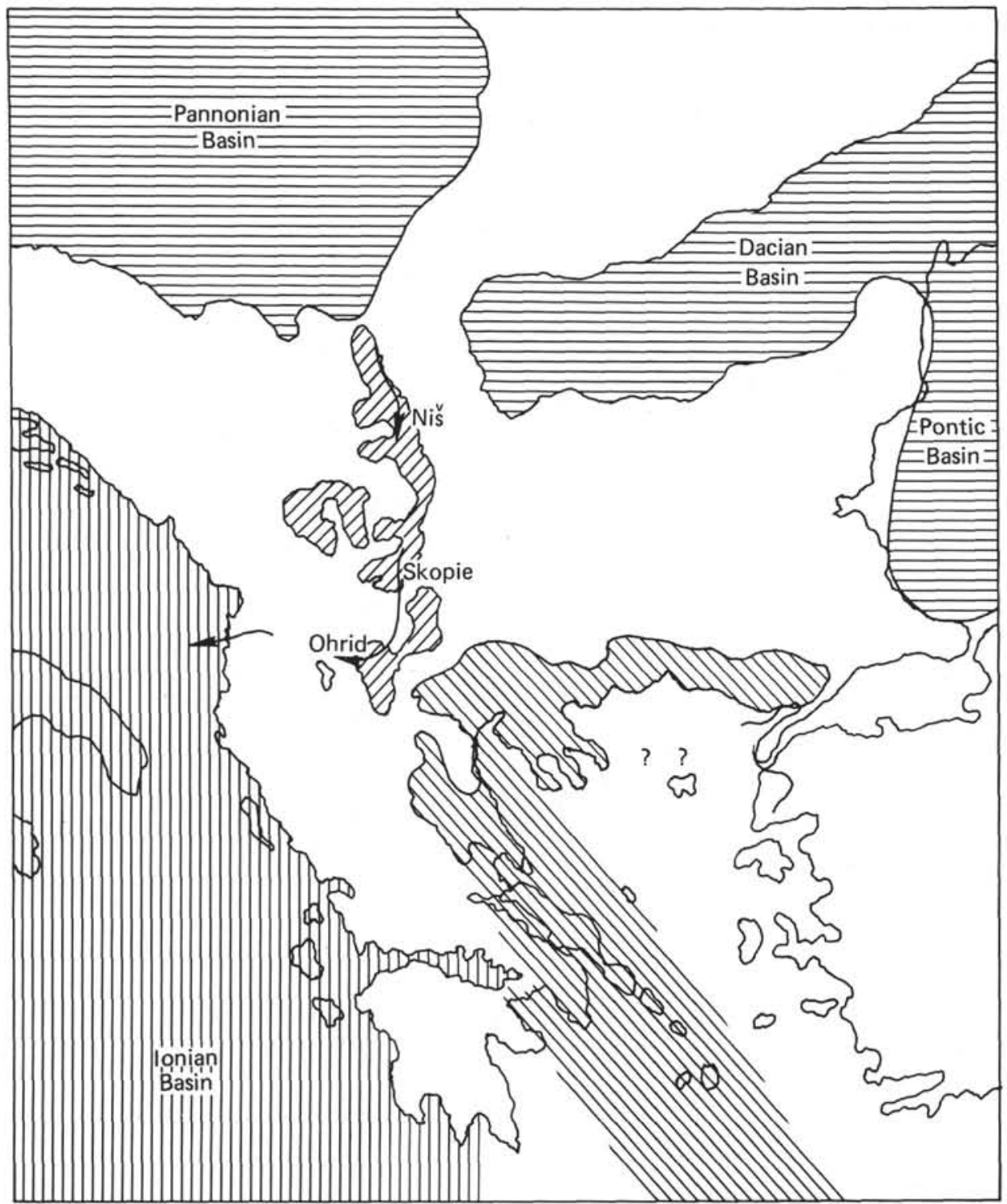

Figure 17. Messinian paleogeography of Paratethys (modified from Stankovic, 1960).
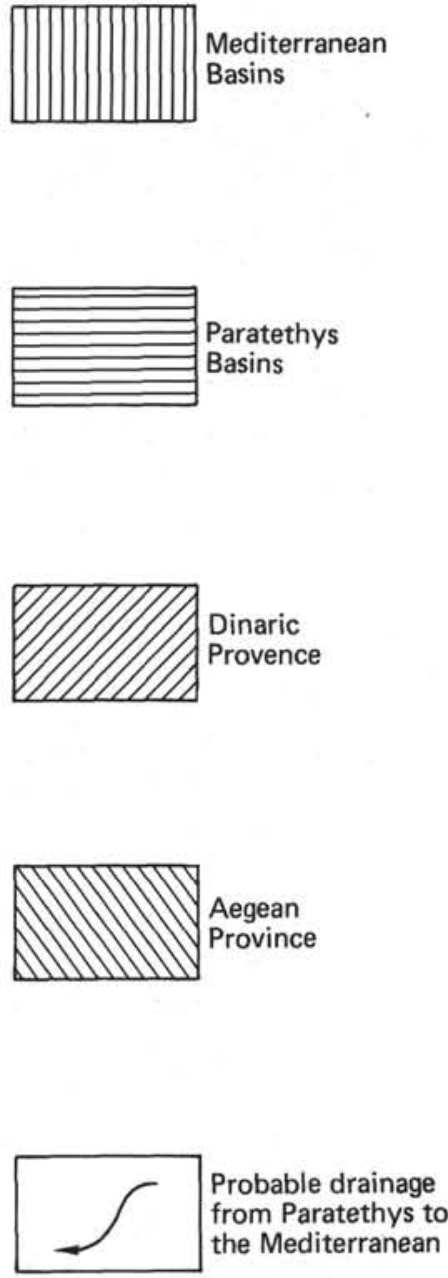
derived from the Pannonian Basin via Nis and Skorpic (Stankovic, 1960). However, the present Aegean faunas, unlike the Dinaric, do not contain relic Tethys or Neoqene circum-Mediterranean thermophilic elements. Stankovic (1960) emphasized that the distinct difference between the present Balkan faunas on the Adriatic and the Aegean coasts cannot be attributed to a climatic difference between two halves of the peninsula. The Aegean faunas today are more recent immigrants from the Black Sea province. The Black Sea drilling results indicate that the Bosporus did not come into existence until the Quaternary. By then, the climate of Paratethys had been chilled sufficiently to kill off the Neogene thermophilic elements. They were replaced by a central European fauna, which eventually went through the Bosporus to populate the rivers and lakes on the Aegean coast of today.

The postulate that the Bosporus was not in existence during the Messinian may explain the fact that "Lago Mare" deposits were not found at our Aegean Site 378; we penetrated the top of the Messinian there, but sampled only a dolomite veneer and selenitic gypsum 14

We have no clearcut answer to the question of whether the "Lago Mare" extended to the western Mediterranean. The Cyprideis fauna is present in land sections in Algeria, Spain, Tuscany, and in Sicily, but is absent, or very doubtfully represented, in our deep-sea bore holes (Cita et al., this volume); the few individuals in the uppermost Messinian cores of Sites 124 and 372 may be reworked specimens. At both of these sites, and at Site 132, the youngest Messinian sediments above the highest gypsum or anhydrite bed, are marine, with dwarfed faunas. They might have been deposited during the initial infilling phase leading to the Pliocene deluge (see discussion by Hsü et al., 1973a, p. 1217-1219).

A brackish-marine sediment was present in Hole 124 (124-13,2) below (not above) some gypsum layers and at about 40 meters below the base of Pliocene (Schrader and Gersonde, this volume). Could this deposit be equivalent to the lower part of the "Lago Mare" sequence of the eastern Mediterranean?

We are now getting into the realm of pure speculation without much solid foundation. It is probable that the marine waters may have spilled over the western basins during the latest Messinian before they reached the eastern Mediterranean. Perhaps the restricted marine facies of the uppermost Messinian in the Balearic and the Tyrrhenian are time equivalent in part to the upper "Lago Mare" deposits. These marine sediments were deposited when the Atlantic water began to refill

\footnotetext{
${ }^{14} \mathrm{One}$ of us (MBC) wished to emphasize the speculative nature of our interpretation of the Messinian connection between the Paratethys and "Lago Mare." We have to wait for the release of information of drilling in the Sea of Marmara before we can finally determine if the Bosporus was indeed a land barrier and not a strait, during the late Miocene. She also felt that the information from Site 378 is too scanty to permit a conclusion that the "Lago Mare" did not extend to the Aegean.
}

the desiccated Mediterranean. The eastern basins beyond the Sicilian Channel were not submerged under marine waters, except for some occasional spillovers. Meanwhile, the peri-continental basins of the west may have remained brackish because of a surplus of freshwater supply, or because they were totally or partially isolated from the deeper Mediterranean basins.

\section{IMPLICATIONS OF THE MESSINIAN SALINITY CRISIS}

The consequences of the Messinian salinity crisis were discussed thoroughly after the Leg 13 cruise (Hsü, et al., 1973a, b; Ryan, 1973; Cita, 1973; Hsü, 1974), and we shall not renumerate these in detail.

The lowering of the base-level of erosion had dire consequences on the Mediterranean drainage system. Valleys carved by the deep cutting of the Rhone, of the Nile, and of other rivers have been traced from far upstream to the edge of Mediterranean abyssal plains (see papers in Ryan, Hsü, et al., 1973; also Gvirtzman and Buchbinder, this volume). New seismic evidence has confirmed that some of these valleys were undoubtedly cut during the Messinian (Montadert et al., this volume) although we do not dispute the fact that submarine canyons of Pliocene-Quaternary age are also common in the Mediterranean province.

The lowering of the base-level and drainage of Paratethys waters to the Mediterranean may have been responsible for the late Miocene development of karst topography in Yugoslavia. Some of us postulated earlier that the so-called "cobble-stone terrains" on the Mediterranean Ridge are buried and modified karst (Hsü et al., 1973a). Drilling at Leg 42A Sites 374, 375, and 376 was interrupted by "lost-circulation" and other anomalous drilling behavior, which could be related to the presence of submarine caverns (see Introduction and Site 375/376 site reports, Chapters 1, 6 , this volume).

The climatic consequence of the salinity crisis was probably a continued change towards a cool and arid climate, and an expansion of the montane coniferous forest vegetation in the circum-Mediterranean regions (Bertolani-Marchetti and Cita, 1975). The global effect can only be speculated upon. We can envision the result of a considerable albedo effect when a clear blue sea was replaced by a shiny white salt desert. This increased albedo effect and expansion of sea ice because of the loss of salts to the Mediterranean may have caused the expansion of polar glaciers (Ryan, 1973). There is indeed some evidence of such an expansion of the Antarctic ice-sheet during the Messinian (Hayes, Frakes, et al., 1974). Arctic ice sheets may also have begun to form at that time (van Hinte, personal communication). It seems probable therefore, that the Messinian salinity crisis may have triggered a glacial period. Conversely, eustatic changes in connection with the build-up or the melting of glaciers may have been responsible for the periodic flooding of the Mediterranean when the Upper Evaporite was deposited (Ryan, 1973; Hsü, 1974; Van Couvering et al., in press). 
The cooling trend initiated during the late Miocene continued in Europe throughout the late Neogene. Thermophilic elements disappeared successively during the late Miocene and Pliocene, before they became extinct altogether with the Quaternary advances of the continental glaciers (Van der Hammen, 1975; Bertolani-Marchetti and Accorsi, this volume; Traverse, in press).

The biogeographical implications of the Messinian crisis have only begun to be explored. The desiccation and the subsequent inundation by the "Lago Mare" should be the key for the understanding of the relic fauna of the circum-Mediterranean regions today (see papers cited in Hsü, 1974).

\section{PLIOCENE FLOODING AND PLIOCENE- QUATERNARY SUBSIDENCE}

Leg $42 \mathrm{~A}$ drilling confirmed the Leg 13 drilling results that the first Pliocene sediments above the Messinian are deep and open marine hemipelagic sediments (Figure 18). The Messinian salinity crisis was ended by the Pliocene flooding. This event is distinguished from Messinian marine incursions by tbe fact that an open communication was firmly established through to the present day; there has been no salinity crisis during the last 5.2 million years! In contrast to the periodic spillovers which might be related to eustatic changes (or to intra-Messinian movements), the Pliocene event was evidently a major tectonic event. It seems logical to assume that movement along Azoras-Gibraltar fracture zone opened a deep gash between the Atlantic and the Mediterranean (see Hsü et al., 1973a; Hsü, 1972). The "dam" at Gibraltar was damaged and broken. A deep connection to the Atlantic was established. Even in the Quaternary, when world wide sea level dropped almost 100 meters, the Mediterranean did not become isolated.

Paleobathymetric analyses indicated that the Pliocene sediments immediately above the Miocene-Pliocene contact invariably were deposited in water depths in excess of 1000 or 1500 meters (Figure 3; also site reports, this volume; Wright, this volume; Benson, this volume). The evidence clearly indicates that deep Mediterranean depressions which had existed prior to the Messinian salinity crisis were still in existence at the end of the crisis. The faunal data can rarely provide evidence to distinguish depth differences in excess of 1500 meters. Seismic evidence demonstrates considerable Pliocene-Quaternary subsidence (Morelli, 1975; Biju-Duval et al., this volume). The subsidence was at least in part induced by the isostatic load of the water flooding the basins (Hsü et al., 1973a, p. 1216-1217; Ryan, 1976). Additional subsidence could be related to cooling of the mantle under the basins, or to continued tectonic activity deepening back arc-basins (Montadert et al., this volume).

There has been considerable discussion as to why the sediments directly overlying the Messinian are not everywhere the oldest Pliocene. The diachronous nature of the basal Pliocene led some to postulate slow

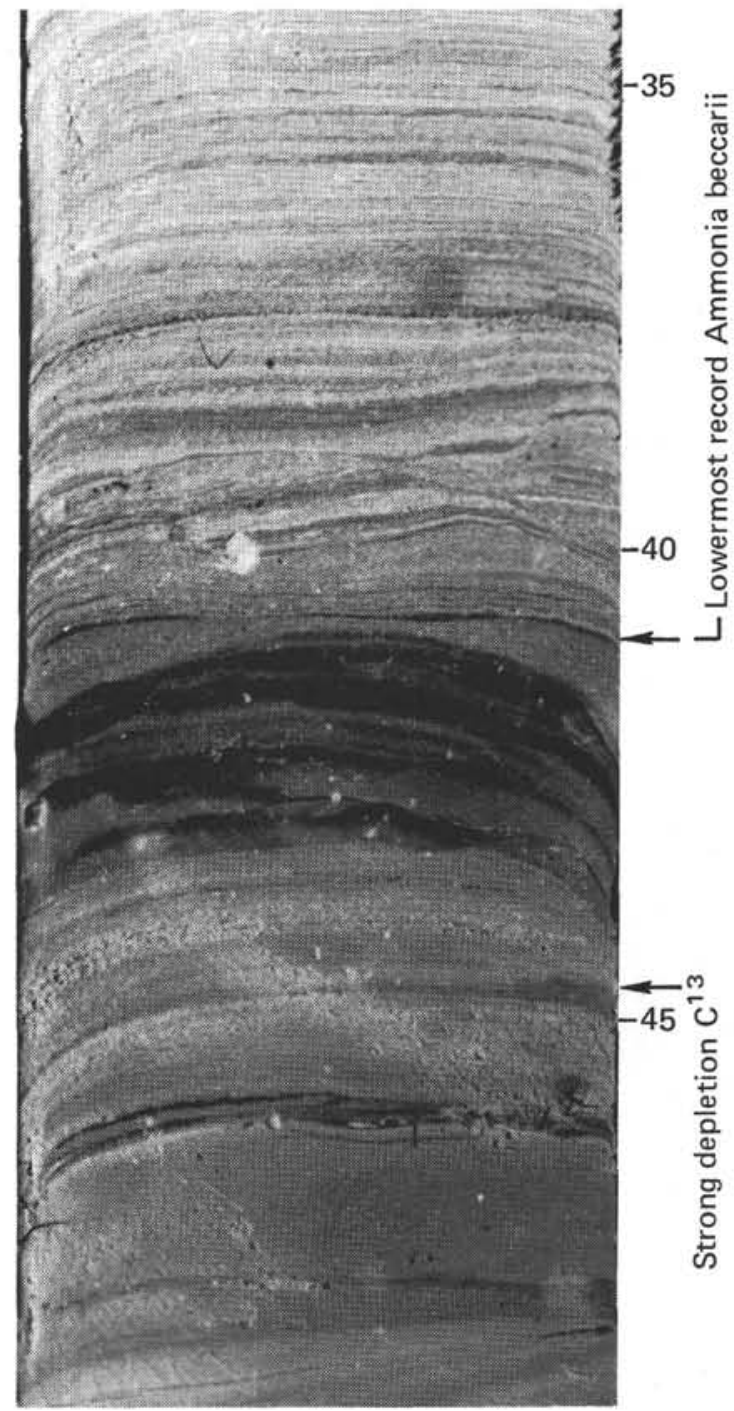

Figure 18. Pliocene/Messinian contact, Site 372 (from Cita et al., this volume). The laminated sediments are Pliocene.

transgression over a gradually subsiding sea bottom (e.g., Wezel, 1974). We wish to emphasize, however, that the Pliocene sediments are entirely different from those one would expect of shallow marine clastics transgressing a shelf sea. The deep-sea drilling has uncovered considerable evidence of submarine unconformity, where bottom currents were active. We prefer to interpret the local post-Messinian hiatus as an interval of non-deposition, when the bottom circulation of the Mediterranean, now with a deep opening to the Atlantic, was very active. Similar regions of nondeposition are present in the eastern Mediterranean today along the paths of its bottom circulation (Fischer and Garrison, 1967).

There has been considerable Pliocene-Quaternary tectonic activity in the circum-Mediterranean regions. The evaporite basins of Sicily, Calabria, the Apennines, the Tellian Atlas, the Ionian Islands, Crete, Cyprus, etc. were uplifted and emerged. Meanwhile continental margins (e.g., the Nile and Rhone deltas, the Israeli 
shelf, etc.) locally underwent subsidence. Such activity has appreciably modified the post-Messinian paleogeography. However, we emphasize that the Mediterranean basins owe their origin to earlier Neogene movements, even though their floors may have been uplifted (as in the Mediterranean Ridge region) or subsided somewhat during the last five million years.

\section{CONCLUSIONS}

The Messinian salinity crisis was an unusual event. This analysis should however serve to show that the event was unavoidable as a consequence of global tectonic development. Except for Hsü and Cita, the Leg 42A shipboard scientific staff boarded Glomar Challenger in Malaga without having formulated conclusions as to the genesis of the Mediterranean Evaporite. Some favored and some opposed the view of a deep basin desiccation model but all arrived with open minds. We had many discussions and debates onboard Glomar Challenger; they became at times acrimonious. We are pleased, however, that the great majority (10 out of 12) of us could finally reach a consensus during our final post-cruise meeting at Granada. Our conclusions can be briefly summarized as follows (see Table 1): Most of the Mediterranean basins of today were already in existence and deep (in excess of $1000 \mathrm{~m}$ or $1500 \mathrm{~m}$ ) prior to the salinity crisis. The basins were partially or totally desiccated more than once during the Messinian. The eastern, and probably some western Mediterranean basins were inundated in the latest Messinian, by continental waters, presumably drained from Paratethys. Near the very end of the Messinian, the Balearic and Tyrrhenian basins began to receive marine waters from the Atlantic, but the environment was not completely open marine. With the opening of the Strait of Gibraltar at the beginning of the Pliocene, all the Mediterranean basins were again submerged under deep and open marine waters. The basins were further deepened by Pliocene-Quaternary subsidence.

\section{ACKNOWLEDGMENTS}

For a major undertaking such as this: a drilling cruise to investigate the Messinian salinity crisis; the efforts of many persons and organizations were indispensable. We cannot acknowledge all our indebtness individually. We would like to thank the U.S. National Science Foundation, the international JOIDES institutions, the various JOIDES Committees and Panels, the Deep Sea Drilling Project, Captain Clarke and his crew, and many others who made our cruise possible. We are indebted to our shore-based investigators; their results helped us in no small way towards formulation of our conclusions.

We would like to mention that it has been a particular pleasure to work with Bill Hay, former chairman of the JOIDES Planning Committee, Hollis Hedberg, Chairman of the JOIDES Safety Panel, Terry Edgar, former Chief Scientist of DSDP, and Mike Pennock, Operations Manager, Leg $42 \mathrm{~A}$, during the various stages of planning and execution of this research. Finally, we would like to make a special acknowledgment of our indebtedness to Bill Ryan. He was a most active member of the Mediterranean Advisory Panel, both before and after its reorganization. He was most helpful in the selection of sites and his interest in the Mediterranean in general and in the salinity crisis in particular, never abated. He voluntarily refrained from offering his services for Leg $42 \mathrm{~A}$, because he sincerely wished that the Leg $42 \mathrm{~A}$ shipboard scientific staff should not be dominated by the holdovers from Leg 13. We appreciated his spirit of selfsacrifice. He is thus not a de jure, but a de facto, co-author of this article.

\section{REFERENCES}

Adams, C. G., 1973. Some Tertiary foraminifera. In Hallam, A. (Ed.), Atlas of paleobiogeography: Elsevier (Amsterdam), p. 453-468.

Adams, C. G. and Ager, D. V., 1967. Aspects of Tethyan biogeography: London (The Systematic Association).

Argand, E., 1924. La Tectonique de l'Asie: Thirteenth Congr. Géol. intern., Bruxelles, Compt. Rend., p. 171-372.

Baroz, F. and Bizon, G., 1974. Le Neogene de la Chaine du Pentedoctylos et de la partie nord de la Meseorie (Chypre): Etude strat. et micropaléo., Rev. Inst. Franç. Pétrole, v. 29 , p. $327-348$.

Baroz, F., Bernoulli, D., Biju-Duval, B., Bizon, G., Bizon, J. J., and Letouzey, J., 1977. Correlations of the Neogene Formation of the Florence Rise and of Northern Cyprus: Paleogeographical and structural implications: this volume.

Benda, L., 1973. Late Miocene sporomorph assemblages from the Mediterranean and their possible paleoclimatological implications. In Messinian events in the Mediterranean: Drooger, C. E. (Ed.), Amsterdam (North Holland Publ. Co.), p. 256-259.

Bertolani-Marchetti, D. and Cita, M. B., 1975. Palynological investigations on Late Messinian sediments recorded at DSDP Site 132 (Tyrrhenian Basin) and their bearing on the deep basin desiccation model: Riv. Ital. Paleontol. Strat., v. 81 , p. 281-308.

Branson, E. B., 1915. Origin of thick gypsum and salt deposits: Geol. Soc. Am. Bull., v. 26, p. 231-242.

Buchbinder, B. and Gvirtzman, G., 1976. The breakup of the Tethys Ocean into the Mediterranean Sea, the Red Sea and the Mesopotamian Basin: a sequence of fault movements and desiccation events (Abstract): First Congr. Pacific Neog. Stratigr., Tokyo, p. 32-35.

Butler, G. P., 1970. Holocene gypsum and anhydrite of the Abu Dhabi Sabkha, Trucial Coast: an alternative explanation of origin, In Rau, J. L. and Dellwig, L. F. (Eds.), Third Symp. Salt, Northern Ohio Geol. Soc., p. 120-152.

Cita, M. B., 1973. Mediterranean evaporite: paleontological arguments for a deep-basin desiccation model. In Drooger, C. W et al. (Eds.), Messinian events in the Mediterranean: Amsterdam (North Holland Publ. Co.), p. 206-228.

Dean, W. E., Davis, G. R., and Anderson, R. V., 1975. Sedimentological significance of nodular and laminated anhydrite: Geology, v. 3, p. 367-372.

Decima, A., 1975. Considerazione preliminari sulla distributione del bromo nella formazione Salina della Sicilia meridionale, preprint of an article to be published in Proc. Messinian Seminar, Erice, Sicily, October 1975.

Decima, A. and Wezel, F. C., 1973. Late Miocene evaporites of the Central Sicilian Basin, Italy. In Ryan, W. B. F., Hsü, K. J. et al., Initial Reports of the Deep Sea Drilling Project, Volume 13: Washington (U.S. Government Printing Office), p. 1234-1244.

Dewey, J. F., Pittman, W. C., Ryan, W. B. F., and Bonin, J., 1973. Plate tectonics and the evolution of the Alpine system: Geol. Soc. Am. Bull., v. 84, p. 3137-3180.

Drooger, C. W., 1973. The Messinian events in the Mediterranean, a review. In Drooger, C. W. et al (Eds.), Messin- 
Jiricek, R., 1975. Paratethys and Tethys Neogene correlation according to ostracoda: Sixth Congr. Regional Comm. on Mediterranean Neogene Stratigraphy, Bratislava 1975, p. 331-335.

Jones, B. F., 1961. Zoning of saline minerals at deep Spring Lake, California, Short Papers in the Geologic and Hydrologic Sciences, Articles 1-146: Geol. Surv. Prof. Paper 324-B, p. 199-202.

Kendall, A. C., 1974. Bromine content of Mediterranean Halite: Comments: Geology, v. 2, p. 522-523.

Kidd, R. B., 1976. In Sicily the Messinian Stage: Geotimes, v. 21 , p. $20-22$.

ian Events in the Mediterranean. Amsterdam (North Holland Publ. Co.) p. 263-272.

Drooger, C. W., Broekman, J. A., Hageman, J., Hantelmann, J. J., Marks, P., Meulenkamp, J. E., and Schmidt, R. R., 1973. Messinian events in the Mediterranean: Geodynamics Sci. Rept. 7, Coll. Utrecht, March, 1973.

Fischer, A. G. and Garrison, R. E., 1967. Carbonate lithification on the seafloor: J. Geol., v. 74, p. 488-496.

Gignoux, M., 1950. Géologie stratigraphique, 4th Ed.: Paris (Masson and $\mathrm{Cie}$ ).

Gheorghian, M. and Popescu, G., 1975. Miocene, micropaleontological guide to the Mesozoic and Tertiary of the Romanian Carpathians, 14th European Micropaleont. Coll. Romanian 1875: Bucharest (Publ. Inst. Geol. Geophys.), p. 49-51.

Hajos, M., 1973. The Mediterranean diatoms. In Ryan, W. B. F., Hsü, K. J., et al., Initial Reports of the Deep Sea Drilling Project, Volume 13: Washington (U.S Government Printing Office), p. 944-969.

Hallam, A., 1973. The Atlas of paleobiogeography: Amsterdam (Elsevier).

Hardie, L. A. and Eugster, H. P., 1971. The Depositional Environment of Marine Evaporite: a Case for Shallow Clastic Accumulation: Sedimentology, v. 16, p. 187-220.

Hayes, D. E., Frakes, L. A., et al., 1975. Initial Reports of the Deep Sea Drilling Project, Volume 28: Washington (U.S. Government Printing Office).

Heimann, K. O. and Mascle, G., 1974. Les séquences de la série evaporitique messinienne: C. R. Acad. Sci. Paris, v. 279 , p. $1987-1990$.

Hsü, K. J., 1972. Origin of saline giants: a critical review after the discovery of the Mediterranean Evaporite: EarthSci. Rev., v. 8, p. 371-396.

1974. The Miocene desiccation of the Mediterranean and its climatical and zoogeographical implications: Naturwissenschaften, v. 61, p. 137-142.

in press. Stratigraphy of Lacustrine sedimentation in the Black Sea. In Ross, D. C., Neprochnov, Y., et al., Initial Reports of the Deep Sea Drilling Project, Volume 42B: Washington (U.S. Government Printing Office).

Hsü, K. J., Montadert, L., et al., 1975. Glomar Challenger returns to the Mediterranean Sea: Geotimes, v. 20, p. $16-$ 19.

Hsü, K. J. and Ryan, W. B. F., 1974. Deep-sea Drilling in the Hellenic Trench: Geol. Soc., Greece Bull. 10, p. 81-89.

Hsü, K. J., Cita, M. B., and Ryan, W. B. F., 1973a. The origin of the Mediterranean Evaporites. In Ryan, W. B. F., Hsü, K. J., et al., Initial Reports of the Deep Sea Drilling Project, Volume 13: Washington (U.S. Government Printing Office), p. 1023-1231.

Hsü, K. J., Ryan, W. B. F., and Cita, M. B., 1973b. Late Miocene desiccation of the Mediterranean: Nature v. 242, p. 240-244.

Hunt, C. B., 1960. Clay mineralogy: New York (McGrawHill Book Co.)
King, R. H., 1947. Sedimentation in Permian Castile Sea: Am. Assoc. Petrol. Geol. Bull., v. 31, p. 470-477.

Kuehn, R. and Hsü, K. J., 1973. Bromine content of Mediterranean halite: Geology, v. 2, p. 213-216.

Meulenkamp, J. E. and Zachariasse, W. J., 1973. Stratigraphic and structural framework of the Messinian deposits on Crete. In Drooger, C. W. et al. (Eds.). Messinian Events in the Mediterranean Sea: Amsterdam (North Holland Publ. Co.), p. 202-206.

Montenat, C., 1973. Le Miocène terminal de chain bêtique (Espagne méridionale), Esquisse Paléogéographique. In Messinian Events in the Mediterranean: Drooger, C. W. et al. (Eds.), Amsterdam (North Holland Publ. Co.), p. 180187.

Moores, E. M. and Vine, F. J., 1971. The Troodos Massif, Cyprus and other ophiolites as ocean crusts: evaluation and implications: Phil. Trans. Roy. Soc., London, Sec. A, v. 268 , p. $443-446$.

Morelli, A., 1975. Geophysics of the Mediterranean, Bulletin de l'étude en commun de la Méditerranée: Spec. Issue 7, CIESM, Monaco, p. 29-111.

Neev, D., Almagor, G., Arad, A., Ginsburg, A., and Hall, J. K., 1976. The geology of the southeastern Mediterranean Sea: Geol. Surv. Israel, Bull. 68, p. 1-57.

Nesteroff, W. D., 1973a. Mineralogy, petrography, distribution and origin of the Messinian Mediterranean Evaporites. In Ryan, W. B. F., Hsü, K. J., et al., Initial Reports of the Deep Sea Drilling Project, Volume 13: p. 673-694, Washington (U.S. Government Printing Office). 1973b. Petrographie des Evaporites messiniennes de La Méditerranée. Comparaison des Forages JOIDESDSDP et des Depots du Bassin de Sicile. In Drooger, C. W. et al. (Eds.), Messinian Events in the Mediterranean: Amsterdam (North Holland Publ. Co.), p. 11-123.

Neumayr, M., 1885. Klimatische Zonen während der Juraund Kreidezeit: Denkschrift K. K. Akad, Wiss., Math.Naturw. kl. 47, p. 177-210.

Papazachos, B. C., 1974. Seismotectonics of eastern Mediterranean Sea. In Solnes, J. (Ed.), Engineering seismology and earthquake engineering: NATO Advanced Study Institutes Series, Ser. E., Appl. Sci., Leiden (Noordhoff), p. $1-32$.

Robertson, A. H. F. and Hudson, J. D., 1974. Pelagic sediments in the Cretaceous and Tertiary History of the Troodos Massif, Cyprus. In Pelagic sediments on land and under the sea: Hsü, K. J. and Jenkyns, H. C. (Eds.), Intern. Assoc. Sedimentol., Spec. Publ. 1, p. 403-436.

Ruggieri, G., 1967. The Miocene and later evolution of the Mediterranean Sea. In Adams, C. G. and Ager, D. V. (Eds.), Aspects of Tethyan biogeography: Syst. Assoc. Publ. No. 7, p. 238.

Ryan, W. B. F., 1973. Geodynamic implications of the Messinian crisis of salinity. In Drooger, C. W. et al. (Eds.), Mediterranean Events in the Mediterranean: Amsterdam (North Holland Publ. Co.), p. 26-38.

1976. Quantitative evaluation of the depth of the Western Mediterranean before, during and after the Late Miocene Salinity Crisis: Sedimentology, v. 23, p.

Ryan, W. B. F., Hsü, K. J., et al., 1973. Initial Reports of the Deep Sea Drilling Project, Volume 13: Washington (U.S. Government Printing Office).

Ryan, W. B. F., Stanley, D. J., Hersey, J. B., Fahlquist, D. A., and Allan, $\Upsilon$. D., 1971. The tectonics and geology of the Mediterranean Sea. In Maxwell, A. (Ed.), The sea: New York (John Wiley \& Sons), v. 4, p. 387.

Savage, R. J. G., 1967. Early Miocene mammal faunas of the Tethyan region. In Adams, C. G. and Ager, D. V. (Eds.), 
Aspects of Tethyan biography: Syst. Assoc. Publ. No. 7, p. 247-282.

Schmalz, R. F., 1970. Environment of marine evaporite deposition: Miner. Ind., v. 35, p. 1-7.

Schreiber, B. C., 1973. Survey of the physical features of Messinian chemical sediments. In Drooger, C. W. et al. (Ed.), Messinian Events in the Mediterranean Sea: Amsterdam (North Holland Publ. Co.), p. 101-110.

Schreiber, B. C., Friedman, G. M., Decima, A., and Schreiber, E., 1976. The depositional environments of the upper Miocene (Messinian) Evaporite deposits of the Sicilian Basin; Sedimentology, v. 23, p. .

Scruton, P. C., 1953. Deposition of evaporites: Am. Assoc. Petrol. Geol. Bull., v. 37, p. 2498-2512.

Selli, R. and Fabbri, M., 1971. Tyrrhenian: a pliocene deep sea: R. C. Accad. Lincei, v. 8, p. 104-116.

Senes, J. (Ed.), 1973. Einleitung in Miozän der zentralen Paratethys: Verl. Slowakischen Akad. Wiss., Bratislava, p. 21-25.

Shackleton, N. J. and Kennett, J. P., 1975. Paleotemperature history of the Cenozoic and the initation of antarctic glaciation: oxygen and carbon isotope an ses in DSDP Sites 277, 279, and 281. In Kennett, J. P., Houtz, R. E., et al. Initial Reports of the Deep-Sea Drilling Project, Volume 29: Washington (U.S. Government Printing Office), p. 743-755

Sissingh, W., 1976. Aspects of late Cenozoic evolution of the South Aegean ostracode fauna: Palaeogeogr., Palaeoclimatol., Palaeoecol., v. 20, p. 131-146.

Smith, A. G., 1971. Alpine deformation and the oceanic areas of the Tethys, Mediterranean and the Atlantic: Geol. Soc. Am. Bull., v. 82, p. 2039-2070.

Stankovic, S., 1960. The Balkan Lake Ohrid and its living world. In Bodenheimer, F. S. and Weisbach, W. W. (Eds.), Monographiae Biologicae: The Hague (W. Junk), v. 9.
Stoffers, P., 1965. Sedimentpetrographische, Geochemische und Paläoklimatische Untersuchungen an Ostafrikanischen Seen, Habilitationsschrift: Universität Hamburg.

Sturani, C., in press. The Messinian in the Tertiary Basin of Piedmont Italy: Proc. Messinian Seminar, Erice (Sicily), October 1975.

Suess, E., 1893. Are great oceans depth permanent?: Nat. Sci., v. 2, p. 180-197.

Sylvester-Bradley, P. C., 1973. A Mediterranean catastrophe: Geol. Mag., v. 110, p. 73-74.

Traverse, A., in press. Palynology of Leg 42B cores. In Ross, D. C., Neprochnov, Y., et al., Initial Reports of the Deep Sea Drilling Project, Volume 42B, Washington (U.S. Government Printing Office).

Vai, G. B. and Ricci Lucchi, in press. Algal and clastic gypsum in a "cannibalistic" evaporite basin: a case history from the Messinian of northern Apennines: Sedimentology, v. 24.

Van Couvering, J. A., Berggren, W. A., Brake, R. E., Aguisse, E., and Curtis, G. H., in press. The terminal Miocene Event: Micropaleontology.

Van der Hammen, T., Wijmstra, T. A., and Zorgwijn, W. H., 1971. The floral record of the Late Cenozoic of Europe, In Turekian, K. (Ed.), The Late Cenozoic glacial ages: New Haven (Yale University Press), p. 391-426.

Vass, D., Slavik, J., and Bagdasarjan, G. P., 1975. Radiometric time scale for Neogene of Paratethys (A State to August 1, 1974): Sixth Congr. Reg. Comm. on Mediterranean Neogene Stratigraphy, Bratislava, p. 293-295.

Wezel, F. C., 1974. Primo Riesame delle Carote Raccolte nel Leg 13 del DSDP (Mediterraneo): Giorn. Geol., v. 39, p. 447-468.

Wong, H. F. and Zarudzki, E. F. K., 1969. Thickness of unconsolidated sediments in the eastern Mediterranean Sea: Geol. Soc. Am. Bull., v. 80, p. 2611. 